\title{
Para que ensinar teoria gramatical $^{1}$
}

\author{
Luiz Carlos Travaglia \\ Universidade Federal de Uberlândia
}

\section{Abstract}

In this paper are discussed some aspects related to teaching gramatical or linguistic theory, in the study of maternal language, in brazilian Fundamental and High School. At same time we try to offer some parameters that aid the teachear: a) to take a decision on working or not with gramatical or linguistic theory in the activities of teaching / learning maternal language in Fundamental and High School; b) about how to teach gramatical theory and the aims of doing this. 


\section{1 - INTRODUÇÃO}

7 odos parecem concordar que as atividades de ensino/ aprendizagem que são desenvolvidas no Ensino Fundamental

1 e Médio devem dar aos alunos algum tipo de formação, em termos de conhecimento e habilidades. Deve-se partir do mesmo pressuposto quando se trata do ensino de língua materna. O tipo de formação, em termos lingüísticos, que queremos dar aos alunos é a resposta para a pergunta: "Para que damos aula de Português para falantes nativos dessa língua?" Assim sendo, essa pergunta e a(s) resposta(s) que dermos a ela são fundamentais para a configuração da ação do professor em sala de aula.

Em outros trabalhos (TRAVAGLIA, 1996, 1996a, 1997, 1998) já buscamos discutir esta questão dos objetivos do ensino de língua materna. Temos assumido sempre a postura de que, nesse ensino, é possível:

a) ensinar a língua, o que resulta em habilidades de uso da língua, e

b) ensinar sobre a língua, o que resulta em conhecimento teórico (descritivo e explicativo) sobre a língua e pode desenvolver a habilidade de análise de fatos da língua.

No primeiro caso o que se busca é a formação de usuários competentes da língua, ou seja, que tenham competência comunicativa. Isso significa ter como objetivo a formação de usuários capazes de usar a língua de modo adequado a cada situação de interação comunicativa, obtendo os efeitos de sentido desejados para a consecução de intenções comunicativas específicas. A meta é conseguir que os alunos tenham maior conhecimento da língua. No 
segundo caso, tem-se a finalidade de ensinar teoria gramatical ou lingüística ${ }^{2}$ (atividades de gramática teórica), formando analistas da língua. A meta é conseguir que os alunos tenham conhecimento sobre a língua e sejam analistas da mesma.

Tendo em vista:

a) que para a esmagadora maioria dos falantes / usuários de uma língua, o que importa é ser comunicativamente competente na mesma; e

b) que ter conhecimento sobre a língua e/ou ser analista da mesma importa a pouca gente (lingüistas, gramáticos, teóricos da língua em geral, professores de língua materna e estrangeira, e em menor grau a alguns profissionais que se valem muito diretamente da linguagem, tais como jornalistas, publicitários, revisores);

temos recomendado que o ensino sobre a língua e, conseqüentemente, de teoria gramatical, seja posto em segundo plano em termos de importância e de tempo gasto com o mesmo no já reduzido tempo de que os professores de Português do Ensino Médio e Fundamental dispõem para o trabalho com a língua materna.

Essa postura nos levou a sugerir que o professor ou elimine o estudo teórico das atividades das aulas de língua materna ou diminua a quantidade de teoria lingüística ou gramatical de que trata em sala de aula, limitando-se, quando muito, a apresentar um quadro mais geral e básico ${ }^{3}$ de conhecimento sobre a língua que permita ao aluno: a) aprofundar seus conhecimentos sobre a língua, caso tenha necessidade disso; b) atender necessidades sócio-culturais; c) utilizar esse conhecimento como meio auxiliar para trabalhos com a língua.

Essa proposta nunca contemplou a eliminação necessária do ensino teórico sobre a língua. Ao contrário, deixou isso como uma opção do professor, a ser feita, todavia, com consciência de fatos, como o já demonstrado de que o ensino de teoria gramatical ou lingüística não leva à formação de usuários competentes da língua, não faz bons produtores e compreendedores de texto (o que é diferente de simples receptores de textos). Neste caso, importa ter 
em mente esse fato, pois as habilidades de produzir e compreender textos competentemente são fundamentais na habilidade lingüística de qualquer falante, já que o fim básico do uso da língua é a comunicação e esta se faz por textos.

A pergunta que o professor se faz e faz aos lingüistas e lingüistas aplicados é: "Deve-se ensinar gramática no Ensino Fundamental e Médio?”. O problema não é só dar uma resposta a tal questão, mas sobretudo é encontrar a resposta adequada, conforme a circunstância e para isso há que se considerar diversos fatores.

Um desses fatores, que em hipótese alguma pode ser desconsiderado, é a própria concepção de gramática que se tem em mente ao fazer a pergunta. Conforme a concepção de gramática, a resposta à questão pode ser necessariamente sim ou não, ou a resposta pode ser um "depende".

Se estivermos concebendo gramática como o próprio mecanismo lingüístico que permite o uso da língua pelos falantes, a resposta é necessariamente "sim", mesmo que o professor tenha priorizado a meta de formar usuários competentes da língua, pois não se pode usar uma língua sem usar sua gramática, sem o conhecimento e uso (automático) dessa gramática. Todavia, neste caso, esse conhecimento não é teoricamente explícito, mas um conhecimento implícito estabelecido na mente do falante de uma forma que os teóricos até hoje não conseguiram explicar nem completa nem devidamente.

Se se estiver concebendo gramática como conjunto de regras sociais para uso da língua (gramática normativa), que são estabelecidas a partir de critérios de natureza menos lingüística e mais políticas, objetivos educacionais mais gerais, o desejável é que a resposta seja sim, para que o aluno possa adquirir o conhecimento e habilidades necessários socialmente para agir lingüisticamente de acordo com o que a sociedade estabeleceu e espera das pessoas. Acresce a isso a razão política de possibilitar ao aluno, sem problemas de compreensão, ter acesso a bens culturais acumulados em determinada forma de língua (a variedade culta em todas as suas formas: científica, literária, oficial, jornalística, etc.). Para nós, entretanto, o ensino de gramática 
normativa não se resume apenas ao ensino de norma culta (embora o domínio dessa variedade da língua tenha capital importância sóciocultural e passar a ser capaz de usá-la seja parte do desenvolvimento da competência comunicativa - TRAVAGLIA, 1996), pois deve ser, na verdade, o ensino das normas sociais para o uso de diferentes variedades da língua.

Se se estiver concebendo gramática como teoria descritivoexplicativa da língua, portanto como teoria lingüística, teoria gramatical, o que levaria o aluno a um conhecimento sobre a língua, a resposta à questão inicial será "ensinar gramática é uma possibilidade" que a nossa consciência de professores pode ou não transformar em fato real. O parâmetro para o professor fazer ou não o percurso possível $\rightarrow$ real será sempre o que ele pretende, suas metas e objetivos, ao dar aula de gramática enquanto teoria descritivoexplicativa da língua.

O objetivo neste artigo é tecer algumas considerações em torno da questão do ensino de teoria gramatical ou lingüística que possam auxiliar o professor em sua decisão sobre trabalhar ou não questões teóricas sobre a língua com seus alunos. Para isto estamos considerando três aspectos:

a) quanto ensinar;

b) o que ensinar;

c) e, fundamentalmente, para que ensinar teoria gramatical ou lingüística.

\section{2 - PARA QUE ENSINAR GRAMÁTICA TEÓRICA}

\section{1 - Preliminares}

2.1.1 - Antes de mais nada é preciso dizer que, mesmo que o professor decida não ensinar teoria a seus alunos, é necessário que ele tenha um conhecimento teórico o mais amplo possível, pois sem esse conhecimento dificilmente o professor saberá estruturar e 
controlar atividades pertinentes de ensino e que realmente caminhem em direção a fins determinados de forma específica e clara. Cremos que isso não se discute, pois é um pressuposto para a configuração de um trabalho metodológico eficiente em sala de aula para o ensino/aprendizagem de língua materna.

2.1.2 - Em segundo lugar, é preciso considerar que, como propusemos em TRAVAGLIA (1996), qualquer aspecto da língua é passível de uma abordagem teórica, uma abordagem não teórica ou uma abordagem normativa, e que todo elemento da gramática da língua pode ser metodologicamente trabalhado usando os quatro tipos de atividades de ensino de gramática propostos e exemplificados: atividades de gramática de uso, reflexiva (que configuram abordagens não teóricas), teórica e normativa. Gostaríamos aqui de exemplificar esse fato, usando um caso da concordância verbal.

Consideremos a regra de concordância verbal quando se tem sujeito composto com os núcleos unidos pela preposição com. Dizem as gramáticas que o verbo pode ir para o singular ou para o plural. A preferência é para o plural, mas o verbo pode ir para o singular se estiver anteposto ao sujeito ou se se quiser dar relevância ao primeiro sujeito (ROCHA LIMA, 1973, p. 361-362 e CEGALLA, 1976, p. 296). Este é um ponto de gramática normativa e pode ser trabalhado com o aluno de várias formas diferentes:

a) se o professor der a regra expositivamente ao aluno (ver exemplo 1) ou o levar a construí-la por meio de um estudo dirigido (ver exemplo 2), estará desenvolvendo atividades de gramática teórica (Cf. proposta de TRAVAGLIA, 1996). Atividades como pedir para justificar ou explicar a concordância já feita ou identificar concordâncias "erradas" (ou seja, que não atendem a norma culta) também devem ser vistas como atividades de ensino teórico de gramática da língua (no caso, um ponto de gramática normativa);

b) se o professor der atividades como exercícios estruturais que apresentam as duas concordâncias e/ou levam o aluno a utilizar as possibilidades de concordância previstas na norma culta, estará 
desenvolvendo atividades de uso da gramática da língua (atividade de gramática de uso na proposta de TRAVAGLIA, 1996) (Ver exemplos 3 a 5). ${ }^{4}$ Exercícios de preenchimento de lacuna com a forma adequada do verbo também seriam atividades de uso;

c) se o professor disser que a regra acima vista é uma recomendação a ser observada por quem desejar usar a língua em sua norma culta, estará fazendo uma atividade normativa desse aspecto da língua (Cf. atividade de gramática normativa na proposta de TRAVAGLIA, 1996). Dizer também que a norma culta não aceita ou recomenda construções como as do exemplo (6) seria atividade de gramática normativa;

d) se o professor pedir ao aluno para discutir diferenças significativas e de possibilidades de utilização das duas concordâncias possíveis em textos e/ou estabelecer em que situação cada uma pode e/ ou deve ser utilizada, estará realizando uma atividade de gramática reflexiva (Cf. proposta de TRAVAGLIA, 1996) (Ver os exemplos 7 e 8).

(1) O professor faria uma exposição semelhante a:

Quando o sujeito 5 é composto e tem os núcleos unidos por "com" o verbo deve, preferencialmente, ir para o plural. Todavia o verbo pode ir também para o singular em dois casos: ${ }^{6}$ a) quando se deseja dar relevância, destaque, importância ao primeiro sujeito; b) se o sujeito estiver posposto ao verbo e o sujeito mais próximo for singular. Também neste caso se tem uma relevância dada ao sujeito mais próximo. Assim sendo, quando o verbo é posto no plural os dois sujeitos são apresentados em pé de igualdade. Quanto à pessoa, segue-se a regra geral: se os dois núcleos forem de terceira pessoa o verbo vai para a terceira pessoa, mas se forem de pessoas diferentes o verbo irá para a pessoa que tem preferência (a primeira pessoa tem preferência sobre as outras duas e a segunda, sobre a terceira). Vamos ver alguns exemplos e discuti-los. 
Exemplos

a) $\mathrm{O}$ presidente com seus ministros chegaram hoje a nossa cidade.

b) $\mathrm{O}$ presidente com seus ministros chegou hoje a nossa cidade.

c) Chegaram hoje a nossa cidade o presidente com seus ministros.

d) Chegou hoje a nossa cidade o presidente com seus ministros.

e) O noivo com sua noiva entraram no salão de festas, sorrindo alegremente.

f) O noivo com sua noiva entrou no salão de festas, sorrindo alegremente.

g) Sorrindo alegremente, entraram no salão de festas o noivo com sua noiva.

h) Sorrindo alegremente, entrou no salão de festas o noivo com sua noiva.

(2) Estudo dirigido

I - Sublinhe os sujeitos das frases abaixo:

a) O presidente com seus ministros chegaram hoje a nossa cidade.

b) O noivo com sua noiva entrou no salão de festas, sorrindo alegremente.

c) Fizeste, tu com teus familiares, algo que ninguém aprova.

d) Partiram para longe a mulher com seu filho.

e) Já tomou lugar no camarote o rei com sua família.

f) Eu com meus colegas exigimos uma explicação.

g) Exijo uma explicação, eu com meus colegas.

h) Exigimos uma explicação eu com meus colegas.

i) Maria com seu marido estavam molhados dos pés à cabeça.

j) Maria com seu marido estava molhada dos pés à cabeça.

k) A Marinha com seus marinheiros cuidará das buscas do barco naufragado. 
1) Os rapazes com suas namoradas dançavam sem parar. m) Dançavam sem parar os rapazes com suas namoradas.

n) Estudava todos os dias o meu filho com seus colegas.

o) Estudavam todos os dias o meu filho com seus colegas.

II - Todos os sujeitos são:

a) simples.

b) __ compostos sem nenhum elemento de união entre os núcleos.

c) compostos com os núcleos unidos por "com".

III - Os verbos aparecem ora antes (antepostos) ora depois (pospostos) do sujeito.

A) Os verbos antepostos ao sujeito:

a) ficaram sempre no plural;

b) ficaram ora no singular ora no plural;

c) ficaram sempre no singular.

Quando estavam antepostos e ficaram no singular concordaram em número e pessoa com quem? ( ) com os dois sujeitos ( ) com o sujeito mais próximo

B) Os verbos pospostos ao sujeito:

d) ficaram sempre no plural;

e) ficaram ora no singular ora no plural;

f) ficaram sempre no singular.

IV - Depois do que você observou acima tente dizer qual é a regra de concordância do verbo com o sujeito, quando o sujeito é composto por núcleos unidos por "com”.

Quando o sujeito do verbo for composto e os núcleos estiverem unidos por "com", o verbo quer esteja

ou ao sujeito. Quando anteposto poderá concordar em número e pessoa com 
(3) Exercício estrutural de repetição

$\mathrm{P}$ - O presidente com seus ministros chegaram hoje a nossa cidade.

A - O presidente com seus ministros chegaram hoje a nossa cidade.

$\mathrm{P}$ - O presidente com seus ministros chegou hoje a nossa cidade.

A - O presidente com seus ministros chegou hoje a nossa cidade.

P - Chegaram hoje a nossa cidade o presidente com seus ministros.

A - Chegaram hoje a nossa cidade o presidente com seus ministros.

P - Chegou hoje a nossa cidade o presidente com seus ministros.

A - Chegou hoje a nossa cidade o presidente com seus ministros.

P - O noivo com sua noiva entrou no salão de festas, sorrindo alegremente.

A - O noivo com sua noiva entrou no salão de festas, sorrindo alegremente.

P - O noivo com sua noiva entraram no salão de festas, sorrindo alegremente.

A - O noivo com sua noiva entraram no salão de festas, sorrindo alegremente.

P - Sorrindo alegremente, entraram no salão de festas o noivo com sua noiva.

A - Sorrindo alegremente, entraram no salão de festas o noivo com sua noiva.

P - Sorrindo alegremente, entrou no salão de festas o noivo com sua noiva.

A - Sorrindo alegremente, entrou no salão de festas o noivo com sua noiva.

P - Eu com minha irmã ajudamos o rapaz ferido.

A - Eu com minha irmã ajudamos o rapaz ferido.

P - Eu com minha irmã ajudei o rapaz ferido. 
A - Eu com minha irmã ajudei o rapaz ferido.

P - Ajudei o rapaz ferido eu com minha irmã

A - Ajudei o rapaz ferido eu com minha irmã

P - Meus irmãos com seus filhos passarão a Semana Santa aqui em casa.

A - Meus irmãos com seus filhos passarão a Semana Santa aqui em casa.

P - Passarão a Semana Santa aqui em casa meus irmãos com seus filhos.

A - Passarão a Semana Santa aqui em casa meus irmãos com seus filhos.

(4) Exercício estrutural de transformação

Modelo: P- O rei com a corte chegou ao Brasil em 1806.

A- O rei com a corte chegaram ao Brasil em 1806.

P - O rei com a corte chegou ao Brasil em 1806.

$\mathrm{P}$ - O presidente com seus ministros chegou hoje a Paris

P - O noivo com a noiva entrou no salão de festas, sorrindo.

P - Eu com meus colegas exijo uma explicação.

$\mathrm{P}$ - O professor de educação física com os alunos preparou o salão de baile.

P - Você com seus sócios comprou o hotel.

$\mathrm{P}$ - João com seus irmãos é muito alegre.

(5) Exercício estrutural de transformação

Modelo: P- O rapaz com sua noiva foram para a lua de mel.

A- O rapaz com sua noiva foi para a lua de mel.

$\mathrm{P}$ - O rapaz com sua noiva foram para a lua de mel.

A - O rapaz com sua noiva foi para a lua de mel.

A - Meu pai com seus irmãos lembraram os tempos de infância.

$\mathrm{P}$ - Eu com meus amigos pediremos autorização ao diretor.

P - João com seus filhos foram expulsos do clube.

A - Você com sua mãe me ofenderam muito. 
P - Pedro com seus irmãos cantam neste bar.

$\mathrm{P}$ - Seu filho com a namorada sempre passam por aqui.

(6) a - *Eu com meus colegas, exigem uma explicação.

b - *Exige uma explicação, eu com meus colegas.

c - *Chegou para a festa meus amigos da faculdade com suas esposas.

d - *Dançava sem parar os rapazes com suas namoradas.

(7) Observe os textos ${ }^{8}$ de cada grupo abaixo. Pense, discuta com seus colegas, imagine em que situações eles seriam usados por alguém e com que finalidade e depois responda:

a) Você acha que os textos de cada grupo significam a mesma coisa? Se não, qual seria a diferença?

b) Você acha que os textos de cada grupo podem ser usados na mesma situação significando a mesma coisa?

c) Dê exemplos de situações em que cada texto poderia ou deveria ser usado e porque ele seria o texto mais adequado para cada situação.

\section{Grupos de textos:}

1) a) Eu com meus colegas exigimos uma explicação.

b) Exijo uma explicação, eu com meus colegas.

2) a) O noivo com sua noiva entraram no salão de festas, sorrindo alegremente.

b) O noivo com sua noiva entrou no salão de festas, sorrindo alegremente.

c) Sorrindo alegremente, entraram no salão de festas o noivo com sua noiva.

d) Sorrindo alegremente, entrou no salão de festas o noivo com sua noiva. 
3) a) O presidente com seus ministros chegaram hoje a nossa cidade.

b) O presidente com seus ministros chegou hoje a nossa cidade.

(8) a) Qual dos textos abaixo você acha que soa melhor aos nossos ouvidos quando falado por alguém? Por quê? (Apenas para o primeiro grupo)

b) Tendo em vista que houve um naufrágio de um barco no litoral de uma praia famosa, provocando grande comoção e interesse da população, qual dos dois textos parece mais conveniente/adequado usar numa situação em que o Ministro da Marinha do Brasil dá uma entrevista para dizer que a Marinha se empenhará com particular interesse nas buscas? Por quê? (Responda separadamente para os dois grupos de textos)

c) No grupo 2 qual texto agradaria mais ao pessoal da Aeronáutica se eles quisessem ter perante o público a mesma importância nas buscas que a Marinha?

Grupo 1

a) A Marinha com seus marinheiros cuidará das buscas do barco naufragado e das pessoas desaparecidas.

b) A Marinha com seus marinheiros cuidarão das buscas do barco naufragado e das pessoas desaparecidas.

Grupo 2

a) A Marinha com a Aeronáutica cuidará das buscas do barco naufragado e das pessoas desaparecidas.

b) A Marinha com a Aeronáutica cuidarão das buscas do barco naufragado e das pessoas desaparecidas.

2.1.3 - Em terceiro lugar o professor que decidir trabalhar com teoria lingüística ou gramatical nas atividades de ensino/aprendizagem de língua materna precisa se lembrar de dois pontos.

O primeiro diz respeito à atenção que o professor deve dar a duas questões: a) a da qualidade da teoria que vai apresentar aos 
alunos; b) a de como vai fazer tal apresentação, pois observa-se que, quase sempre, ela tem sido feita com uma postura de que a teoria (às vezes uma simples hipótese) representa uma verdade inquestionável, quando se sabe que toda teoria nada mais é do que uma tentativa de descrição da língua e/ou de sua forma de funcionamento. É preciso ver se a teoria que estamos apresentando ao aluno é coerente e descreve o mais adequadamente possível os fatos sob consideração. Sobre esse ponto já falamos em TRAVAGLIA (1996, cap. 12) e por isso não vamos nos estender aqui, mas o que dizemos mais adiante sobre crítica a teorias existentes pode ajudar o leitor a entender melhor de que estamos falando aqui.

O segundo ponto, que deriva do primeiro, diz respeito ao fato de que, se teorias lingüísticas / gramaticais são tentativas de descrição / explicação dos fatos / fenômenos da língua, pode haver, e geralmente há, diversas teorias e/ou hipóteses que buscam descrever / explicar o mesmo fato / fenômeno da língua ou de várias línguas. Além disso, diferentes correntes lingüísticas de pressupostos básicos diversos podem mostrar aspectos distintos sobre dado elemento da língua, mas todos válidos. Isso também pode ser feito por estudiosos distintos até mesmo dentro da mesma corrente ou teoria.

Assim, por exemplo, se o professor quer mostrar teoricamente para os alunos que o que chamamos de "palavras" na verdade engloba elementos de naturezas diversas com papéis diversos no uso da língua para a comunicação por meio de textos e, portanto, que as palavras desempenham papéis distintos na composição / constituição de textos, ele terá que trabalhar com o que a teoria tem chamado de classes de palauras ou partes do discurso. O que a escola tem feito no Ensino Fundamental e Médio, é, talvez sem qualquer variação, trabalhar com as classes de palavras propostas pela teoria da Lingüística Tradicional, que propõe dez classes de palavras: substantivo, adjetivo, verbo, pronome, numeral, artigo, preposição, conjunção, advérbio, interjeição. Quase sempre os professores ensinam as classes de palavras, dando: a) conceitos que permitiriam distinguir as dez classes de palavras e que são formulados com base 
em critérios semânticos e/ou sintáticos e/ou morfológicos; b) subtipos de algumas classes de palavras; c) flexões da classes de palavras variáveis. Quase nunca se trata do emprego das classes de palavras. A teoria da gramática tradicional todavia não é a única existente sobre as classes de palavras no Português. Há outras teorias como as relembradas a seguir.

1) A classificação de palavras proposta por CÂMARA JÚNIOR (1970), no capítulo sobre "A classificação dos vocábulos formais". Câmara Júnior, usando um critério morfo-semântico, propõe que haveria quatro classes de vocábulos formais: nome, verbo, pronome e conectivo. Do ponto de vista funcional os nomes e pronomes podem se subdividir em substantivo, adjetivo e advérbio. Ou seja, na verdade esses três termos não identificam classes de palavras distintas, mas funções distintas de duas classes de palavras: os nomes e os pronomes. Se os conectivos fazem de um termo o determinante de outro eles são subordinativos (e incluem o que a gramática tradicional chama de conjunções e preposições), se apenas adicionam um termo a outro são coordenativos. Câmara Júnior admite a existência de elementos que são híbridos em sua natureza: é o caso dos chamados pronomes relativos, que seriam a um só tempo pronomes e conectivos. Câmara Júnior não dá maiores detalhes, mas percebe-se que o artigo integra a classe dos pronomes e os numerais, a classe dos nomes. Quanto à interjeição, ele nada explicita.

2) A classificação de palavras proposta por SCHNEIDER (1977), que usa como justificativa o fato de se estar tratando de morfologia e não de sintaxe e semântica, para adotar um critério apenas morfológico para propor cinco classes de palavras: nomes (englobando o que tradicionalmente se divide em substantivo, adjetivo e numeral, porque admitem derivação e flexão em gênero e número), pronome, verbo, advérbio e conectivos (que engloba as tradicionais preposição e conjunção, porque não admitem derivação nem flexão). 
O critério mórfico de Schneider se baseia no uso ou não de "sufixos" flexionais ou derivacionais e sua teoria se resume no QUADRO 1.

\section{QUADRO 1}

Classes de palavras segundo SCHNEIDER (1977)

\begin{tabular}{|c|c|c|c|c|c|c|c|c|c|c|}
\hline \multirow{3}{*}{ Classes } & \multicolumn{5}{|c|}{ + Derivação } & \multicolumn{5}{|c|}{ - Derivação } \\
\hline & \multicolumn{4}{|c|}{ + Flexão } & \multirow[t]{2}{*}{-Flexão } & \multicolumn{4}{|c|}{ + Flexão } & \multirow[t]{2}{*}{-Flexão } \\
\hline & Gênero & №. & №/Pes. & $\mathrm{T} / \mathrm{M}$ & & Gênero & № & №/Pes. & $\mathrm{T} / \mathrm{M}$ & \\
\hline 1.Subst & $\mathrm{X}$ & $\mathrm{X}$ & & & & & & & & \\
\hline 2.Adj. & $\mathrm{X}$ & $\mathrm{X}$ & & & & & & & & \\
\hline 3.Num. & $\mathrm{X}$ & $\mathrm{X}$ & & & & & & & & \\
\hline 4.Pron. & & & & & & $\mathrm{X}$ & $\mathrm{X}$ & $\mathrm{X}$ & & \\
\hline 5.Verb. & & & $\mathrm{X}$ & $\mathrm{X}$ & & & & & & \\
\hline 6.Adv. & & & & & $\bar{X}$ & & & & & \\
\hline 7.Conj. & & & & & & & & & & $\mathrm{X}$ \\
\hline 8.Prep. & & & & & & & & & & $\mathrm{X}$ \\
\hline
\end{tabular}

\section{Legenda}

$\begin{array}{llll}\text { Subst.: Substantivo } & \text { Adj.: Adjetivo } & \text { Num.: Numeral } & \text { Pron.: Pronome } \\ \text { Verb.: Verbo } & \text { Adv.: Advérbio } & \text { Conj.: Conjunção Prep.: Preposição } \\ \text { №: número } & \text { Pes.: Pessoa } & \text { T: tempo M: modo }\end{array}$

Para Schneider, o artigo e a interjeição não são classes de vocábulos: o artigo seria um morfema vocábulo marcador de gênero e número dos nomes e a interjeição seria apenas um elemento da linguagem emotiva e não da linguagem intelectiva. A distinção entre substantivo e adjetivo é apenas uma subclassificação sintática de nomes e pronomes;

3) A classificação de palavras proposta por PERINI (1995) (Cf. também PERINI, 1978). Este autor, agindo de acordo com algumas opções teórico-metodológicas de estudo e descrição da língua, não chega a fazer uma proposta completa de classificação de palavras, mas chama a atenção para questões importantes a serem 
levadas em conta quando se trabalha com classificação de palavras. Para sua proposta de classificação, Perini adota os seguintes princípios:

a) O estabelecimento de classes é necessário para permitir fazer afirmações gramaticais com o máximo de economia e assim fazer uma descrição da estrutura da língua com a maior economia possível;

b) A classificação de palavras pode ser feita do ponto de vista sintático ou semântico. A classificação sintática deve ser feita separadamente da semântica e somente depois as duas devem ser relacionadas. Perini opta por fazer a classificação sintática das palavras, ou seja, estabelecer quais seriam as classes de palavras usando critérios sintáticos;

c) Qualquer classificação a ser feita deve atender a objetivos específicos, pois a classificação pode mudar conforme o objetivo que se tem. Tendo em vista o objetivo de estudo da língua, que para o autor é descrever a estrutura da língua do ponto de vista gramatical, no caso das palavras da língua, as classes propostas precisam ser pertinentes, úteis para esta descrição;

d) As classes serão definidas por traços que são características morfológicas, sintáticas ou semânticas que servem para classificar as palavras, e a meta da classificação é "agrupar aquelas que têm comportamento gramatical semelhante" (p. 312);

e) Há classes abertas (aquelas que têm um inventário aberto de palavras que pertencem à classe) e fechadas (aquelas que têm um inventário limitado de palavras, conhecidas por todos os falantes da língua).

Com base nesses princípios, Perini esboça um início de classificação de palavras e estabelece algumas classes que ele diz serem ainda "provisórias", levantando problemas que, segundo ele, demandam ainda muita pesquisa para serem resolvidos. Basicamente o que ele deixa estabelecido é o que expomos a seguir. ${ }^{10}$ 
Segundo PERINI (1995), a lista completa das classes de palavras do português ainda não pode ser dada, porque as classes ainda não foram pesquisadas de forma mais ampla e abrangente. Para ele, algumas classes já estariam razoavelmente estabelecidas pelo critério sintático que ele adota, mas, mesmo que ele utilize em alguns casos nomes semelhantes ao da classificação tradicional, é preciso estar atento, pois o critério de classificação é bem outro e, na maioria dos casos, as palavras pertencentes a cada classe diferem do que se vê tradicionalmente. As classes já razoavelmente definidas seriam:

a) O verbo que é definido como a classe de palavras que variam em pessoa, tempo e número, e a única que pode desempenhar a função de núcleo do predicado (NdP);

b) Os substantivos e os adjetivos, cuja definição e abrangência é completamente diferente dessas classes na gramática tradicional, começando pelo fato de que Perini não admite o que se diz tradicionalmente de substantivo que funciona como adjetivo ou adjetivo que se substantiva em dados contextos.

Para Perini os substantivos são "todas as palavras que podem ser complementos do predicado (têm o traço $[+\mathrm{CP}])^{11} \mathrm{e}$ não podem ser nem modificadores [- Mod] nem predicativos [-Pv]" (p. 327) e os adjetivos "são as palavras que podem ser complementos do predicado $[+\mathrm{CP}]$, e também modificadores [+Mod] e predicativos [+Pv]". Esses são os traços definidores e distintivos, mas as duas classes têm outros traços que permitem distinguir duas subclasses de substantivos (que ele chama de substantivos-1, que não podem coocorrer com outro termo dentro do sintagma nominal [-T,SN], e substantivos-2, que podem coocorrer com outros termos dentro do sintagma nominal [+T,SN]), e duas classes de adjetivos (que ele chama de adjetivos-1, os que podem ocorrer com intensificador [+Int _ ], e adjetivos-2, que não podem ocorrer com intensificador [- Int__]). A subclasse dos adjetivos 1 tem quatro subclasses definidas pela presença ou ausência de quatro outros traços que também entram na definição dos substantivos. Por essa pequena exposição, pode-se perceber que sua classificação é totalmente 
diversa do que tradicionalmente se vê. Assim, por exemplo, os substativos-1 correspondem aproximadamente à classe dos pronomes substantivos da gramática tradicional;

c) Após fazer diversas críticas à teoria da gramática tradicional sobre os pronomes, Perini diz que a classe dos pronomes tradicionais tem de desaparecer e propõe uma nova classificação para as palavras tradicionalmente incluídas nessa classe, que pode ser assim resumida: os pronomes tradicionais pertencem, na verdade, a diversas classes, em função de seu comportamento sintático, a saber:

c.1 - substantivos-1: eu, nós, ele, isto, aquilo, etc.

c.2 - substantivos-2: alguém, ninguém, tudo, algo, etc.

c.3 - relativos e interrogativos [+ Rel]: que, quem, o qual, etc.

c.4 - pré-determinantes [+Pdet]: todos, ambos.

c.5 - determinantes [+Det]: o, um, algum, este, esse, aquele, etc.

c.6 - possessivos [+Poss]: meu, seu, nosso, etc.

c.7 - quantificadores [+Qf]: muitos, vários, diversos, único, terceiro, etc.

c.8 - numeradores [+Num]: outro, dois e os demais cardinais.

Como se pode perceber, o que tradicionalmente pertence a apenas uma classe (a dos pronomes), PERINI (1995) coloca em oito classes distintas que não são subclasses de pronomes;

d) Outra classe, que para PERINI (1995) estaria razoavelmente bem estabelecida, é a dos conectivos, embora haja muitos problemas a serem resolvidos. Ele distingue dois tipos de conectivos:

d.1 - Os conectivos subordinativos, que são aqueles que têm "como função sintática alterar a classe de um sintagma nominal ou de uma oração", ou seja, "acrescentar-se a um sintagma nominal ou a uma oração, formando um sintagma maior que pertence a outra classe que não o sintagma nominal ou a oração". Para Perini há três subclasses de conectivos subordinativos: a) as preposições, que são palavras que precedem um sintagma nominal, formando, 
o conjunto, um sintagma adjetivo ou um sintagma adverbial (Ex.: a, até, com, de, em, para, por, sem, etc.); b) as conjunções, que são palavras que precedem uma oração, formando, o conjunto, um sintagma adverbial ou um sintagma nominal; c) os relativos, que são palavras que se acrescentam a uma oração para formar um sintagma adjetivo (que, o qual, quem, cujo, onde, quanto). Os relativos têm a característica, diferente dos demais conectivos, de assumir uma função sintática na oração a que se agregam.

d.2 - Os conectivos coordenativos, que são os que têm "como função sintática juntar dois (ou mais) constituintes de mesma classe, formando, o conjunto, um constituinte maior que pertence à mesma classe dos constituintes conectados". Para Perini, os conectivos coordenativos típicos seriam $e$ e ou. Os demais (mas, pois, nem, que, porque, etc.) se assemelham a eles, mas apresentam muitos comportamentos particulares que ainda precisam ser estudados.

e) PERINI (1995) questiona a existência da classe tradicional dos advérbios, tendo em vista que as palavras tradicionalmente incluídas nessa classe exercem funções sintáticas muito diversas tais como: negação verbal, intensificador, adjunto circunstancial, atributo, adjunto adverbial e adjunto oracional. Para Perini, as palavras da "classe" tradicionalmente chamada de "advérbio" ainda estão muito mal estudadas.

Como se pode verificar, a proposta de Perini busca deixar claros seus princípios, pressupostos e objetivos e, baseando-se apenas no critério do comportamento sintático das palavras, longe de propor uma classificação de palavras que reduza as classes tradicionalmente postas, como fazem CÂMARA JÚNIOR (1970) e SCHNEIDER (1977), o autor vem estruturando uma classificação mais complexa do que a tradicional, mas, segundo ele, mais precisa e pertinente para a descrição gramatical da língua. 
4) Além dessas propostas, ainda se pode lembrar que a teoria lingüística vem estabelecendo, por critérios vários, classes de palavras que nem tradicionalmente, nem em correntes mais formais da Lingüística foram consideradas. Estão nesse caso as classes:

a) dos marcadores conversacionais, especialmente pertinentes na língua falada e levantada pela análise da conversação (cf. a esse respeito os estudos do Projeto de Gramática do Português Falado, publicados pela Editora da UNICAMP, em Campinas, SP);

b) dos operadores argumentativos, especialmente pertinentes para os estudos sobre argumentação na língua e propostos pela Semântica Argumentativa. Essa classe inclui elementos de várias classes, como a das conjunções da gramática tradicional, outros tipos de conectores, como os estudados pela Lingüística Textual ao tratar da coesão textual seqüencial por conexão (KOCH, 1989, 1992) e palavras que a gramática tradicional qualificava como de difícil classificação e situava quase sempre após o capítulo do advérbio como "partículas denotadoras" de realce, inclusão, exclusão, designação, etc.

Com esse exemplo, queremos mostrar que não há uma única e definitiva resposta para a mesma questão e que não se pode dar ao aluno a impressão de que isso ocorre. Não estamos dizendo que o professor deve trabalhar com diversas teorias no ensino fundamental e médio. Tudo depende de seus objetivos, do nível dos alunos, mas não se pode desconhecer esses fatos da ciência, nem deixar os alunos com uma visão e, conseqüentemente, uma postura equivocada sobre o estudo científico da língua, que, geralmente, gera preconceitos e/ ou sensações de incompetência frente à própria língua que fala.

Atento a esse fato, se o professor decide abordar teoricamente com os alunos um aspecto da língua, ele terá que decidir se vai trabalhar com uma ou mais de uma teoria (nesse caso comparando postulados, pressupostos, propostas e análises), descartando outra(s) existente(s). Para escolher a(s) teoria(s) a ser(em) trabalhada(s) em sala de aula, ele pode se valer de critérios diversos tais como: a) seus 
objetivos para dar teoria; b) a qualidade da teoria, ou seja, se ela é capaz de descrever / explicar todos os elementos envolvidos no fato / fenômeno em observação (ou pelo menos uma parte significativa deles); c) sua simplicidade; d) se a(s) teoria(s) chama(m) a atenção para aspectos que se considera importante observar, descrever, explicar nas atividades de ensino/aprendizagem.

Tudo isso, certamente, tem conseqüências, que não se pode desprezar, na estruturação do ensino de língua materna e das atividades de ensino/aprendizagem que o concretizam.

2.1.4 - Em quarto lugar, queremos lembrar que se pode trabalhar com ensino de gramática teórica, com metalinguagem lingüística, visando a diferentes objetivos. Queremos dar maior atenção a esse aspecto e, por isso, vamos tratá-lo à parte no item 2.2 a seguir.

\section{2- Razões para ensinar teoria gramatical}

Parece que todos estão de acordo com a proposição de que o objetivo maior e prioritário do ensino de Língua Portuguesa, como língua materna, no Ensino Médio e Fundamental, é a formação de usuários competentes da língua, capazes de, em situações específicas de interação comunicativa, produzir textos (orais e / ou escritos) que sejam adequados à produção de determinados efeitos de sentido para a consecução de dada intenção / objetivo específico de comunicação; e, ao mesmo tempo, capazes de compreender os textos (orais e/ou escritos) que recebem, estabelecendo / percebendo sentido(s) adequado(s) à forma como cada texto se apresenta construído, ao contexto sócio-histórico-ideológico e à situação imediata de comunicação em que ele está sendo utilizado como meio ou instrumento para a comunicação. Isso significa trabalhar com a competência comunicativa do falante. Tendo em vista que todo falante nativo tem competência no uso de pelo menos uma (ou algumas) variedade(s) da língua quando chega à escola, o objetivo mais pertinente e importante do ensino de língua materna seria 
desenvolver a competência comunicativa desse falante, ou seja, possibilitar que ele seja capaz de utilizar, de modo adequado, variedades da língua em que ele não tem competência ou tem competência limitada, levando-o a usar adequadamente cada vez um maior número de recursos disponíveis na língua para a produção de efeitos de sentido e, conseqüentemente, para a comunicação competente (cf. o que foi posto por TRAVAGLIA, 1996, sobre os objetivos para o ensino de língua materna).

Já dissemos na introdução que o conhecimento teórico da língua e a habilidade de descrevê-la e analisá-la explicitamente só interessam diretamente a certas categorias profissionais e não à maioria das pessoas. Pressupondo que também se esteja de acordo com o que parece ser consenso entre os estudiosos da questão, de que o ensino de metalinguagem, de teoria gramatical ou lingüística, desenvolvido por meio de atividades de gramática teórica, não é um recurso, um instrumento para atingir o objetivo tão desejável de desenvolver a competência comunicativa (cf. BECHARA, 1985, LEMINSKI, 199?, LUFT, 1985, PERINI, 1978, 1986 e 1995, POSSENTI, 1997, SUASSUNA, 1995 e TRAVAGLIA, 1996), permanece sempre a pergunta: deve-se ou não trabalhar com teoria gramatical no Ensino Fundamental e Médio? Em caso afirmativo, para quê? Com que objetivos? Que razões justificariam ainda o ensino de teoria nesse nível escolar?

Apesar de não servir ao objetivo de desenvolver a competência comunicativa (que é uma habilidade), há razões para acreditar que se deve, em algum momento, trabalhar teoricamente com o aluno para a consecução de outros objetivos ligados à aquisição de conhecimentos e/ou de habilidades não especificamente lingüísticas, mas altamente desejáveis do ponto de vista educacional em geral (cf. IGNÁCIO, 1993, KATO, 1988, LOPES, 1976, MARQUARDT \& GRAEFF, 1986, PERINI, 1978, 1985 e 1995 e TRAVAGLIA, 1996). Até onde pudemos observar (em todo o nosso tempo de atenção ao ensino de língua materna e de prática do mesmo e atento ao que dizem outros trabalhos sobre a mesma questão), pode-se ensinar 
teoria no Ensino Fundamental e Médio, basicamente, com três objetivos que aparecem resumidos no QUADRO 2. Já que estamos descartando de princípio que o ensino de teoria possa servir ao objetivo de desenvolver as habilidades de produção e compreensão de textos orais e escritos, tendo razões diversas para não acreditar nesta possibilidade, não vamos mais discutir aqui esta questão.

\section{QUADRO 2}

\begin{tabular}{|l|l|l|}
\hline \multicolumn{1}{|c|}{ Objetivos } & Estratégias para atingir o objetivo \\
\hline 1 & Dar informação cultural & \\
\hline 2 & $\begin{array}{l}\text { Instrumentalizar com recursos } \\
\text { para aplicações práticas imediatas }\end{array}$ & \\
\hline 3 & $\begin{array}{l}\text { Desenvolver o raciocínio, } \\
\text { a capacidade de pensar, } \\
\text { ensinar a fazer ciência }\end{array}$ & $\begin{array}{l}\text { a) Redescobrir teorias existentes } \\
\text { b) Criticar teorias existentes } \\
\text { c) Criar, formular teorias }\end{array}$ \\
\hline
\end{tabular}

\subsection{1 - Objetivo 1: Informação cultural}

Parece evidente que conhecimentos de teoria gramatical resultantes dos estudos da Lingüística, enquanto ciência de estudo da língua (conhecimentos teóricos sobre a língua) não têm aplicação prática imediata para a maioria das pessoas e profissões. Assim, por exemplo, médicos, mecânicos, motoristas, donas de casa, agricultores, lavadores de carro, dançarinos, comerciários, bancários, engenheiros, marceneiros, eletricistas, etc. não precisam, para exercer sua profissão ou mesmo para atividades não-profissionais comuns na sua vida, de conhecimentos teóricos sobre a língua. Estamos falando de conhecimentos tais como os que se adquirem ao estudar: a) análise sintática: termos da oração e suas funções e classificação de orações no período composto; b) as pessoas do discurso; c) classificação de palavras; d) reconhecimento e classificação de unidades lingüísticas tais como fonemas, morfemas (gramemas, lexemas), semantemas, orações, períodos, frases; e) classificação de figuras de linguagem; f) transfor- 
mações sintáticas; g) classificação de palavras quanto ao número de sílabas, h) reconhecimento de ditongos, hiatos, dígrafos; i) etc.

Todos hão de concordar que muito dificilmente os profissionais citados e a grande maioria das pessoas em sua vida precisarão, por exemplo, identificar um objeto direto ou qualquer outro termo da oração, classificar orações, classificar algo como metáfora ou metonímia, identificar fonemas, estabelecer semantema de qualquer lexema, classificar palavras e assim por diante. Este é um forte argumento para não se trabalhar com teoria gramatical no ensino fundamental e médio e para dizer que isso será função de cursos nas áreas de Letras e Lingüística ou de outros diretamente responsáveis por formação de profissionais que trabalham com a língua. Isso pode ser verdade, mas uma certa dose de conhecimento teórico-científico da língua pode ser necessário, se lembrarmos que nossa sociedade e cultura, hoje, valorizam a ciência e são muito voltadas para ela e que a sociedade exige de seus cidadãos conhecimentos que, embora aparentemente não tenham qualquer aplicação imediata à vida prática, são vistos como importantes para a formação do indivíduo, do cidadão. Este, sem tais informações, terá um conhecimento de mundo com lacunas que podem atrapalhar sua adequada compreensão dos discursos que circulam na sociedade e seu acesso a várias áreas da vida sócio-cultural, vistas como fundamentais para adquirir consideração social e melhor qualidade de vida. Numa sociedade científica como a de hoje, conhecimentos básicos das diversas ciências são necessários para uma comunicação razoável em diversas situações quer como produtores, quer como recebedores de textos.

Concordamos, pois, totalmente com PERINI (1995), quando diz que as razões que justificam um conhecimento de teoria gramatical sobre a língua (entendido como explicitação de sua estrutura e funcionamento e não apenas de uso correto $^{12}$ da mesma) e seu estudo no Ensino Médio e Fundamental são as mesmas que justificam a preocupação de propiciar ao aluno conhecimentos de outras ciências (Física, Química, Biologia, Matemática, História, Geografia, Sociologia, etc.), que certamente não terão aplicações práticas imediatas em sua vida profissional ou não-profissional. Mas, como 
diz PERINI (1995, p. 30), "essa massa de informações científicas é parte importante do corpo de conhecimentos comuns às pessoas instruídas, e sua presença nos permite a comunicação no nível exigido pela sociedade moderna”. Isso quer dizer que podemos participar de trocas comunicativas por meio de textos como os elencados em (9), pois eles pressupõem conhecimentos de mundo sem os quais será impossível produzi-los ou compreendê-los. Além do mais, se estudamos outras questões sociais abordadas por outras ciências, por que não estudar justamente o resultado do trabalho de uma das mais importantes ciências humanas e sociais, a Lingüística, que estuda justamente o fenômeno social (a língua), que perpassa todas as situações de nossa vida e praticamente dá forma a tudo o que somos, pensamos, sentimos, inclusive como grupo social e cultural? Complementarmente, conhecimentos teóricos sobre a língua que usamos, sua estrutura, seu modo de funcionar, suas variedades, sua história, sua função de expressão da nossa cultura, fazem com que o estudo sobre a mesma tenha implicações nas questões ligadas à nacionalidade, orgulho e amor-próprio nacional e preservação cultural.

(9) a - Ele come comida sem sal porque não tolera o sódio. ${ }^{13}$

b - Descobriram que na via-láctea há diversos buracos negros.

c - Não sei se este verbo se conjuga desse modo.

d - Quais são os afluentes do Rio Paranaíba no Triângulo Mineiro?

f - A gravidade exige que se gaste muito combustível no lançamento de foguetes.

g - Para resolver o racionamento vão fazer algumas usinas nucleares no Brasil.

h - Ele está com problemas de digestão porque sua vesícula biliar não está funcionando bem.

i - Adoro as metáforas usadas por Adélia Prado.

j - Seu texto é uma narrativa muito interessante.

Portanto pode-se propor o estudo de teoria gramatical ou lingüística para atender uma exigência cultural de nossa sociedade, na formação de uma massa de conhecimentos que se espera que 
todo cidadão instruído dessa sociedade domine. Seguindo essa linha de raciocínio, resta ainda, a nosso ver, o grande problema de selecionar em toda a massa de conhecimento gerada pelos estudos lingüísticos quais são os tópicos que realmente interessam culturalmente a cada cidadão e em que grau de profundidade e detalhamento abordar cada um. Em outras palavras é a resolução do que e quanto deste conhecimento é pertinente estudar com os alunos do Ensino Fundamental e Médio. Cremos que dificilmente as pessoas chegariam a um consenso sobre essa questão, mas permanece a sugestão de PERINI (1988) de que se dê um quadro geral e não muito aprofundado/ detalhado da estrutura da língua. Minimamente, parece-nos, poderse-ia tratar dos seguintes aspectos da língua: a) as unidades lingüisticas mais fundamentais em cada nível (fonológico, morfológico, sintático, semântico) e plano (lexical, frasal, textual); b) as flexões e as categorias que elas expressam; c) as diferentes categorias gramaticais (gênero, número, pessoa, voz, tempo, modalidade e aspecto); d) um conhecimento teórico básico sobre construções sintáticas; e) processos de formação de palavras e elementos lingüísticos usados em tais processos (radicais, prefixos, sufixos); f) o funcionamento de todos estes recursos da língua em textos para permitir a comunicação, incluindo aí noções básicas de textualidade, pragmática e argumentatividade; g) a noção de variedades lingüísticas e o conhecimento dos tipos de variedades existentes; h) a discussão das normas sociais de uso dessas variedades lingüísticas, o que incluiria uma visão teórica sobre norma culta, se possível livre dos preconceitos que têm sido inculcados pelo ensino normativo tradicional; i) mais algum tópico que algum colega julgue pertinente e importante ser incluído nessa massa básica de conhecimentos sobre a língua, sobretudo levando-se em conta o contexto em que a língua está sendo ensinada. Evidentemente, o leitor já estará dizendo que essa listagem nada tem de específico e ajuda muito pouco o colega professor. Concordo plenamente, mas digo também que se trata antes do primeiro esboço do projeto de um trabalho a ser realizado, e não de uma resposta dada à questão. 
Sem sombra de dúvida, um parâmetro para incluir algum tópico neste estudo teórico a ser feito na escola de nível fundamental e médio é o atendimento ao segundo objetivo para ensinar teoria gramatical ou lingüística do qual passamos a falar a seguir.

\subsection{2 - Objetivo 2: Instrumentalizar com recursos para aplicações práticas}

É importante lembrar que alguns conhecimentos teóricos sobre a língua podem ter e têm aplicações práticas imediatas na vida das pessoas, em suas atividades profissionais ou do dia-a-dia, e, por isso, devem ser estudados nas aulas de língua materna. PERINI (1995, p. 29) acha que tal aplicação imediata "talvez" seja "bastante modesta". Concordamos com ele. Alguns exemplos disso seriam:

a) O conhecimento do alfabeto e da chamada ordem alfabética é indispensável, por exemplo, se a pessoa precisa encontrar uma palavra no dicionário. Outra aplicação desse conhecimento está na organização e consulta de fichários com fins diversos, arquivos e assemelhados, bem como organização de listagens em geral;

b) O conhecimento das flexões e da forma gramatical básica com que a palavra aparece nos dicionários é necessário quando alguém encontra em um texto uma palavra flexionada, portanto não na forma com que ela aparece dicionarizada, e precisa consultar o dicionário para saber o significado ou outras informações sobre a palavra. Assim, se houver a palavra encontrávamos, sem o conhecimento de que é um verbo e que aparece no dicionário no infinitivo (encontrar), a pessoa pode ficar na dúvida e não saber localizá-la, já que, no dicionário, aparecem outros itens lexicais com o mesmo radical e significados aproximados: encontrada, encontrado, encontrão, encontrar, encontrável, encontro, encontroada e encontroar ${ }^{14}$

c) O conhecimento teórico das flexões e suas denominações pode ser necessário quando alguém precisa considerar a adequação de certos usos a uma determinada variedade lingüística. Isso acontece 
com maior freqüência em relação à variedade culta da língua. Um exemplo disso seria o caso das concordâncias nominal e verbal, que não podem ser adequadamente consideradas sem o conhecimento das flexões de gênero, número e pessoa;

d) O conhecimento teórico das convenções da língua escrita têm, obviamente, aplicação prática imediata para alguém que esteja produzindo um texto escrito. Como exemplo pode-se lembrar:

d.1 - as regras de divisão silábica, necessárias a quem precise dividir sílabas em final de linhas;

d.2 - as regras básicas de pontuação, para evitar, por exemplo, que uma interrogação seja interpretada pelo leitor como uma afirmativa;

d.3 - as regras de distribuição do escrito na folha de papel, tais como: o uso de margens, afastamento para marcar parágrafos, mudança de linhas marcando mudança de interlocutor (o que se indica simultaneamente pelo uso do travessão, que é um aspecto da pontuação), centralização e destaque no título do texto no topo da página.

Uma aplicação prática imediata que pode levar o professor a ensinar teoria gramatical, ou pelo menos pode justificar o ensino de uma certa parte da teoria gramatical, dando ao aluno nomenclatura e noções conceituais e/ou prática de análise sobre determinados elementos da língua é a possibilidade de poder usar tal conhecimento como recurso auxiliar no ensino da língua, servindo como meio auxiliar, mediação na discussão de elementos da língua, por exemplo, em atividades de gramática reflexiva, de uso ou normativa (TRAVAGLIA, 1996). O que se tem então é o domínio pelo aluno de nomenclaturas para facilitar a referência a elementos da língua que são foco nas atividades. O professor então poderia dizer coisas como: este verbo, esta conjunção ou este conectivo, este operador argumentativo, esta oração, este parágrafo, o presente do indicativo ao contrário do pretérito imperfeito do indicativo, esta estrutura; em vez de usar termos gerais, menos técnicos e de conhecimento mais 
comum, tais como: esta palavra (no lugar de verbo, conjunção ou conectivo, operador argumentativo), este trecho (no lugar de oração, parágrafo) e esta forma (no lugar de presente do indicativo e pretérito imperfeito do indicativo), esta construção ou este jeito de dizer (no lugar de esta estrutura). É sempre possível referir os elementos da língua sem usar a nomenclatura técnica, mas parece não haver como escapar de algumas concepções teóricas básicas como as noções de palavra, texto, construção sintática. Vejam-se os exemplos (7) e (8) e o exemplo (10) abaixo em três versões.

Há ainda uma necessidade de conhecimento teórico e de nomenclatura, que vale também para outras áreas do saber. Em diversas circunstâncias, as pessoas têm que estar instrumentalizadas para falar de uma forma mais técnica, não empregando termos muito genéricos, pois isto pode gerar imprecisões indesejáveis em determinadas situações de interação comunicativa. Isso tem a ver com o desenvolvimento da competência comunicativa, pois relaciona-se ao uso de variedades da língua: aqui um registro quanto à sintonia na dimensão da tecnicidade. ${ }^{15}$ De certa forma isso se relaciona com a informação cultural, discutida anteriormente.

10.1 - Diga a diferença de sentido entre os dois textos abaixo e que acontece devido ao uso, em um, do presente do indicativo e, em outro, do futuro do pretérito do verbo emprestar. Tente dar exemplo de uma situação em que seria mais adequado usar cada texto.

a) Você me empresta sua caneta?

b) Você me emprestaria sua caneta?

10.2 - Os dois textos abaixo não significam a mesma coisa. Sua diferença de sentido acontece porque em um foi usada a forma empresta e no outro a forma emprestaria (ambas são formas de emprestar). Qual a diferença de sentido entre os dois textos? Você acha que tanto faz usar um ou outro? Quando seria bom usar um e quando seria mais conveniente usar o outro? 
a) Você me empresta sua caneta?

b) Você me emprestaria sua caneta?

10.3 - Os dois trechos abaixo têm uma única diferença: cada um foi construído com uma forma diferente do verbo emprestar. Você acha que os dois trechos significam a mesma coisa? Têm exatamente o mesmo sentido? Se sim, qual é o sentido dos dois? Se não, diga qual é a diferença de sentido que você notou e diga em que casos (situações) você acha que seria mais conveniente usar um ou outro trecho.

a) Você me empresta sua caneta?

b) Você me emprestaria sua caneta?

Ao dar teoria gramatical com a justificativa de usar o conhecimento adquirido como recurso didático auxiliar para consecução do objetivo de desenvolver competência comunicativa, o professor deve ter atenção e cuidado para não se esquecer de tratar a teoria apenas como uma mediação, um recurso auxiliar, sem torná-la de novo o centro e o fim das aulas de língua materna.

\subsection{3 - Objetivo 3: Desenvolver o raciocínio, a capacidade de pensar, ensinar a fazer ciência.}

O objetivo de desenvolver o raciocínio, a capacidade de pensar, de ensinar a fazer ciência é um objetivo educacional mais amplo e não especificamente do ensino de língua materna. Para atender esse objetivo, o professor deverá buscar desenvolver no aluno a habilidade de, diante de fatos do mundo (natural ou social) ser capaz de observar, formular hipóteses e buscar sua comprovação ou falsificação. Com isso dar-se-ia à aula de teoria gramatical ou lingüística um caráter de um momento de pesquisa, o que desenvolveria nos alunos uma habilidade que lhes daria independência intelectual, por adquirirem uma capacidade de pensar que lhes permitiria, como diz PERINI (1995, p. 31), "aprender por si mesmos, criticar o que aprendem e criar conhecimento novo". 
Evidentemente, isso daria aos participantes de atividades dessa natureza a certeza de que a verdade sobre qualquer fato ou fenômeno do mundo natural e/ou social não está pronta em livros e dita por autoridades de qualquer tipo, mas que as hipóteses e teorias das ciências constituem um corpo de conhecimento que pode ser criticado, reelaborado, refutado, ser acrescido de novas descobertas, pois dificilmente se terá dito a última palavra sobre qualquer fato ou fenômeno, inclusive os da língua. Pode-se fazer com que o aluno, observando os fatos, perceba que nem mesmo as normas sociais para o uso da língua (gramática normativa) são uma lei imutável, já que a língua é essencialmente dinâmica e está mudando constantemente por razões diversas, inclusive para atender novas e/ou maiores necessidades comunicacionais da sociedade e cultura a que a língua serve. Ele perceberá que, na verdade, as normas sociais de uso da língua são escolhas da sociedade baseadas muito menos em razões lingüísticas e mais em razões de prestígio social (político, econômico, cultural) (o que explica sua importância), de tradição, de preservação da cultura e da identidade nacional, de estética, de maior ou menor eficiência comunicacional entre outras.

A busca de consecução desse objetivo pode e deve ser feito pelos professores de todas as disciplinas; todavia o professor de Português como língua materna tem a vantagem de contar com um fato presente em todos os momentos da vida social de todas as pessoas e cujo estudo apresenta, como aula de ciência, algumas vantagens importantes, tendo em vista as condições de nosso sistema de ensino, que geralmente tem poucos ou nenhum recurso:

a) O material lingüístico é fartamente disponível, tanto na modalidade escrita quanto na oral e não precisa ser comprado. Basta levantar dados, observando certos princípios metodológicos básicos, para evitar não só problemas na análise, mas também o repasse de procedimentos inadequados aos alunos;

b) O trabalho científico com a língua, salvo raras exceções (como no caso de estudos mais sofisticados de fonética), não depende de laboratórios e/ou instrumentos; 
c) Pode-se contar com a intuição de falante nativo dos alunos, de modo que o pesquisador pode observar a si mesmo;

d) O trabalho com a língua é mais suscetível de despertar o interesse dos alunos, uma vez que o uso da língua é fundamental em todos os setores e momentos da vida (inclusive no estudo das demais disciplinas).

As questões para estudo podem ser levantadas tanto na observação dos usos lingüísticos do dia-a-dia quanto nas teorias existentes que muitas vezes sugerem, por si ou dizem explicitamente, questões a serem abordadas. Estas precisam ter um grau de dificuldade ou profundidade que permite a sua abordagem no Ensino Fundamental e Médio, e o professor pode e deve controlar até onde ir com os alunos, de modo a desenvolver a habilidade desejada, para não adentrar problemas cuja dificuldade ou profundidade ultrapassam o estágio de desenvolvimento dos alunos.

De qualquer modo, teremos como resultado final o fato de termos pessoas mais capazes intelectualmente, cientes e confiantes de que não só podem aprender teorias científicas (gramática), mas também podem descartá-las, modificá-las e, melhor ainda, construílas. Isso é, sem dúvida, uma habilidade altamente desejável, pois hoje, mais importante que acumular conhecimento, é ter as habilidades necessárias à sua busca, crítica, seleção para fins específicos e à sua construção.

O desenvolvimento das habilidades de que vimos falando pode ser feito por meio de três tipos de estratégias e atividades que se configuram com três propósitos distintos que apresentamos a seguir.

\subsubsection{1 - Redescobrir teorias existentes}

O professor pode desenvolver atividades que levem o aluno, a partir da observação dirigida de dados, a redescobrir teorias existentes, anteriormente elaboradas por outrem. Este tipo de trabalho tem sido desenvolvido no ensino tradicional de língua materna, em atividades que os livros didáticos têm chamado de 
"estudo dirigido". Nesses casos leva-se o aluno a elaborar conceitos diversos (geralmente os da gramática tradicional a partir da NGB) ${ }^{16}$ identificando elementos da estrutura morfológica, lexical e sintática da língua, e a enunciar regras, tais como as oficiais de acentuação e as normativas de concordância verbal e nominal.

Esse tipo de atividade está exemplificado em (2) e em (11) abaixo. Em TRAVAGLIA (1996, p. 144-149) pode-se ver alguns exemplos extraídos de livros didáticos.

A) Observe os textos abaixo e coloque:

a) Se o fato expresso ocorre antes do momento em que a pessoa está falando/ escrevendo.

b) Se o fato expresso ocorre no momento em que a pessoa está falando/escrevendo.

c) Se o fato expresso ocorre após o momento em que a pessoa está falando/ escrevendo

( ) Seu irmão vai ao cinema conosco hoje à noite?

( ) Maria esteve doente.

( ) Meu filho está assistindo televisão.

( ) Eu não participei da corrida de São Silvestre no fim do ano.

( ) Todos serão contratados por nossa empresa.

( ) ( ) O menino tinha saído / quando a mãe chegou em casa.

( ) Sua mãe falava demais.

( ) Ele anda estudando muito para o concurso.

( ) Maria olhou para fora viu a água escorrendo na vidraça e disse: - Chove!

Ao indicarmos se a ocorrência dos fatos é anterior, simultânea ou posterior ao momento em que se fala / escreve estamos exprimindo:

( ) o modo de ocorrência dos fatos.

( ) o tempo de ocorrência dos fatos.

( ) o lugar de ocorrência dos fatos.

( ) a certeza ou não certeza da ocorrência dos fatos. 
B) Observe os textos abaixo e escreva antes de cada um se o fato tem ocorrência anterior (passada ou pretérita), posterior (futura) ou simultânea (presente) ao momento em que se fala / escreve.

a)

b)

C)

d)

e)

f)

g) Maria vai ler este livro para o concurso. Maria leu este livro para o concurso. Maria está lendo este livro para o concurso. Maria tinha lido este livro para o concurso. Maria lerá este livro para o concurso. O que Maria está fazendo? Maria lê este livro para o concurso. Maria, leia este livro para o concurso!

Em relação aos textos vistos em $\mathrm{B}$, responda:

a) Qual é o único elemento dos textos que varia e que, portanto, podemos dizer que seria o responsável pela expressão do fato como tendo ocorrência anterior, simultânea ou posterior ao momento em que se fala / escreve?

b) Portanto a indicação do momento de ocorrência de um fato como anterior, simultâneo ou posterior ao momento em que se fala / escreve é feita pelas formas do

c) Pelo observado nos textos de A e B acima o indica ocorrência anterior (passada ou pretérita), simultânea (presente) ou posterior (futura) em relação ao momento em que diz (falando ou escrevendo) algo:

( ) usando sempre uma mesma forma para indicação de anterioridade, outra para indicação de simultaneidade e outra para indicação de posterioridade em relação ao momento em que se diz. 
( ) usando diversas formas diferentes para indicação de anterioridade, diversas formas para indicação de simultaneidade e diversas formas para indicação de posterioridade em relação ao momento em que se diz.

d) Se a indicação de um fato como tendo ocorrência anterior (passada ou pretérita), simultânea (presente) ou posterior (futura) em relação ao momento em que se fala sobre esse fato é uma indicação de tempo e se essa indicação é feita pelas formas verbais, podemos dizer que tempo verbal é

C) Agora procure, em textos, exemplos de trechos em que os fatos expressos estejam no tempo passado, presente ou futuro (pelo menos cinco exemplos de cada e, de preferência, com formas verbais diferentes).

Veja se você encontra, nos textos, trechos em que não se pode dizer que a forma do verbo esteja no passado, ou no presente, ou no futuro. Copie-os e traga para sala de aula para discussão com os colegas sobre se eles não têm indicação de tempo ou se a indicação de tempo é algo diferente do visto até agora.

A última atividade, proposta em $C$ acima, abre espaço para o professor levar o aluno a descobrir que pode haver formas verbais usadas sem marcação / indicação de tempo (cf. $a$ abaixo) e formas que indicam onitemporalidade (Cf. $b$ e $c$ abaixo), passado até o presente (cf. $d$ e $e$ abaixo) ou presente para o futuro (cf. $f$ abaixo).

(11.1) a) Viver é preciso.

b) João é muito esperto.

c) João fuma muito.

d) Meu neto tem me visitado todas as semanas.

e) Os cientistas vinham avisando sobre esta possibilidade de um desastre ecológico.

f) Vocês vão lendo este texto até que eu volte da biblioteca. 
Sem dirigir tanto a "redescoberta", como no estudo dirigido, o professor pode também levar o aluno a redescobrir uma teoria existente por um tipo de atividade em que o aluno termina por formular uma teoria igual ou muito próxima a uma já existente. Veja o exemplo (12). Nosso objetivo é tão só dar uma idéia de como a atividade pode se desenvolver, por isso não detalhamos com exemplos em cada passo. Além disso, com certeza, muito do que acontecerá e será feito e discutido, dependerá do desempenho de cada grupo de alunos na tarefa.

(12) O professor pode desenvolver uma atividade, para levar os alunos a formularem uma teoria de classes de palavras, que siga aproximadamente os seguintes passos:

1) Inicialmente pedirá aos alunos para que leiam diversos textos escritos e orais, observando atentamente e buscando dividir as palavras dos textos lidos em dois grupos:

a) aquelas que se referem a algo do mundo físico, biológico, psicológico ou social;

b) aquelas que não indicam algo do mundo físico, biológico, psicológico ou social e por isso têm um sentido mais interno à língua.

O professor daria exemplos para orientar os alunos. Assim entrariam nos dois grupos palavras como:

a) casa, pedra, caminhar, quebrar, grande, redondo, vinte, terceiro, ambos, dobro, quíntuplo, etc. (mundo físico); árvore, flor, peixe, bem-te-vi, homem, viver, crescer (mundo biológico); amor, ciúme, esperança, afetuoso, querido, amável, simpatizar, odiar, amar, (mundo psicológico); José, pai, patrão, guarda-roupa, diretor, amigo, atrasado, ilegal, aceitável, desrespeitoso, reunir, festejar (mundo social);

b) o, um, ele, nós, meu, seu, todos, quem, ${ }^{17}$ de, para, com, sem, sobre, entre, pois, porque, e, mas, enquanto, já que, lá, aqui, hoje, agora, ai, oh. ${ }^{18}$ 
Estar-se-ia estabelecendo com base em um critério semântico duas grandes classes de palavras: as lexicaise as gramaticais, que já foram propostas. Essa classificação, embora muito difundida e consensual, não é desprovida de problemas quanto ao que se inclui em cada uma delas (veja as notas 17 e 18). Essa terminologia de palavras lexicais e gramaticais pode ser sugerida aos alunos (mas aí estaríamos mais no campo do estudo dirigido) ou pode-se pedir a eles que proponham nomes para identificar as duas classes (o que estaria mais de acordo com o espírito do tipo de atividade que estamos exemplificando). Essa questão terminológica se apresentará a cada passo de formulação da teoria e não vamos repeti-la nos próximos passos. A primeira classe estaria incluindo mais ou menos o que a teoria tradicional chama de substantivos, adjetivos, verbos e numerais e a segunda estaria incluindo aproximadamente o que a teoria tradicional chama de artigos, pronomes, advérbios, conjunções, preposições e interjeições e mais os marcadores conversacionais. Isso já representaria uma subclassificação que os alunos ainda não fizeram neste passo

O primeiro passo já representaria a "redescoberta" de uma teoria existente, mas, se quiser, o professor pode continuar realizando passos como os sugeridos a seguir.

2) O professor pode pedir aos alunos para ver se as palavras do primeiro grupo podem ser divididas em subgrupos de acordo com o tipo de flexão que aceitam: gênero, número, tempo, modo, número e pessoa. Isso pode ser feito, usando um conhecimento teórico prévio sobre as flexões, o que sem dúvida facilitaria a aplicação desse critério morfológico, ou verificando realmente as variações de forma gramatical a que as palavras do grupo 1 podem ser submetidas. O aluno, pela observação, chegaria a dois subgrupos de palavras pelo critério morfológico: a) as que aceitam as flexões indicadoras de gênero e número e b) as que aceitam flexões para indicar 
número, pessoa, tempo e modo. Isso corresponderia mais ou menos às classes dos nomes (incluindo aproximadamente o que a teoria tradicional chama de substantivos, adjetivos e numerais ${ }^{19}$ ) e dos verbos (correspondente à classe tradicional dos verbos) propostas por CÂMARA JÚNIOR (1970). Não se deve esquecer a questão da nomenclatura para a designação dessas duas subclasses.

3) Após o estabelecimento das classes do passo 2, o professor pode pedir aos alunos que apliquem às palavras do grupo 1b o mesmo critério morfológico aplicado, no passo 2, às palavras do primeiro grupo. No final da observação e estudo, o aluno deverá perceber que algumas aceitam flexões indicadoras de gênero e número e indicam pessoa lexicalmente, embora não se flexionem para indicar essa categoria gramatical e que outras não se flexionam de modo algum. Teríamos assim duas subclasses: a) uma constituída por palavras que se flexionam para indicar gênero e número e indicam pessoa lexicalmente; b) outra constituída por palavras que não se flexionam. Na primeira classe estariam incluídas as palavras que a teoria tradicional chamou de artigos (para muitos seriam pronomes de terceira pessoa com função exclusivamente anafórica e correlacionados com a indicação de informação nova/dada) e pronomes e que CÂMARA JÚNIOR (1970) reuniu na classe dos pronomes. Na segunda classe estariam todas as palavras que não admitem flexão, incluindo aproximadamente as classes que a teoria tradicional chamou de preposições, conjunções, advérbios, interjeições e mais os marcadores conversacionais. Resta dar nomes a essas duas classes.

4) Num quarto passo, pode-se introduzir um critério sintático. Para os grupos já estabelecidos, poder-se-ia observar, por exemplo, quais as palavras:

A) que só podem aparecer: a) sozinhas no texto, sem qualquer determinante acompanhando-as; b) ou como 
constituinte determinado de um sintagma, ou seja, como aquilo a que a gramática tradicional chama de núcleo de um termo;

B) que podem aparecer tanto sozinhas (sem qualquer determinante) no texto, quanto como constituinte determinado ou como constituinte determinante de um sintagma;

C) que só podem aparecer acompanhando outras palavras ou sintagmas do texto como determinantes de oração, de sintagma, de um constituinte de sintagma ou com outras funções na cadeia lingüística.

Provavelmente o aluno iria chegar a conclusões mais ou menos semelhantes às seguintes constatações:

a) que as palavras da primeira classe do passo 2 (palavras que aceitam flexões de gênero e número: os nomes de Câmara Júnior) se dividiriam pelos três grupos acima (A, $\mathrm{B} \mathrm{e} \mathrm{C}$ ), o que corresponderia mais ou menos aos dois tipos de substantivos e à classe dos adjetivos de PERINI (1995);

b) que as palavras da segunda classe do passo 2 (palavras que aceitam flexões de número-pessoa e tempo-modo) seriam todas do grupo A, ou seja, os verbos só aparecem sozinhos por si mesmos no texto ou como determinado, constituindo sempre o sintagma verbal;

c) que as palavras da primeira classe do passo 3 (pronomes de Câmara Júnior) pertenceriam algumas ao grupo A (pronomes substantivos como eu, ele, quem, isto, etc.), incluindo-se sintaticamente numa das classes de substantivos de PERINI (1995) (substantivos-1), junto com um grupo de palavras do passo 2;

d) que as palavras da segunda classe do passo 3 têm comportamentos diferentes:

- algumas parecem não ter qualquer ligação sintática com qualquer outro elemento do texto, ou seja, nunca são nem determinados nem determinantes, $\mathrm{O}$ 
que seria um grupo à parte dentro do grupo A. Estamos falando do que a teoria tradicional chamou de interjeição e que alguns estudiosos disseram ser uma palavra-frase (CÂMARA JÚNIOR,1974); ${ }^{20}$

- outras parece que são sempre determinantes de algum elemento do texto: verbo, sintagma verbal, oração, adjetivos (da teoria tradicional ou de PERINI, 1995), mas com funções sintáticas muito diferentes: negação verbal, intensificador, adjunto circunstancial, atributo, adjunto adverbial, adjunto oracional (segundo a proposta de PERINI, 1995, p. 340). Corresponde aproximadamente ao que a teoria tradicional incluiu na classe dos advérbios;

- outras não são capazes de aparecer sozinhas por si mesmas no texto, mas também não aparecem nem como determinados nem como determinantes em sintagmas. Na verdade elas parecem ter a função de, nos sintagmas oracionais (= uma oração) e supra oracionais (= um período ou parte dele), estabelecer uma ligação entre dois elementos da cadeia lingüística (são as palavras que a teoria tradicional chamou de preposições e conjunções e CÂMARA JÚNIOR, 1970 chamou de conectivos). Tal ligação pode ser feita de dois modos diferentes, como já vimos com CÂMARA JÚNIOR (1970) e PERINI (1995) e também na teoria tradicional, configurando a dependência (subordinação) de um elemento a outro, ou a igualdade (coordenação) entre dois ou mais constituintes que se juntam em um constituinte maior de mesma natureza dos que se juntam;

e) provavelmente o aluno encontraria todas as questões que colocamos em notas e em observações nas conclusões acima e que representam problemas a serem resolvidos. 
Como dissemos, há a questão terminológica a ser resolvida para todas essas classes e subclasses encontradas pelo critério sintático proposto em A, B e C.

5) Um quinto passo poderia ser constituído pela tentativa de correlacionar as classes e subclasses encontradas pelos diferentes critérios aplicados nos passos anteriores. Algumas dessas questões de relacionamento entre as classes encontradas pelos diversos critérios já foram registradas anteriormente.

6) Conforme o tempo disponível, o desempenho dos alunos e a pertinência para a formação intelectual dos mesmos, o professor poderia ainda, sem dificuldades, introduzir passos que fossem refinando e aprofundando a "formulação / redescoberta" da(s) teoria(s), mas cremos que chegar até o passo 5 já seria mais do que suficiente para o Ensino Médio e talvez até um pouco demais para o Ensino Fundamental.

Como se pode perceber em nossos comentários, nos diversos passos sugeridos para a atividade, estar-se-ia trabalhando com a "redescoberta" de propostas formuladas por diversas teorias que buscaram lançar luzes sobre vários aspectos e problemas envolvidos na classificação de palavras, o que também deve deixar claro para o leitor, mais uma vez, porque e como é problemático apresentar ou trabalhar uma teoria com os alunos como se a mesma fosse a verdade incontestável.

\subsubsection{2 - Criticar teorias existentes}

O professor conhece diversas teorias gramaticais e lingüisticas sobre diferentes aspectos da língua e problemas que elas apresentam. Nesse caso o professor pode montar atividades que levem os alunos a verificar a validade ou não de dada teoria, testando-as face aos dados lingüísticos para constatar se elas descrevem adequadamente ou não a estrutura e/ou o funcionamento da língua em relação ao 
elemento em foco. Tal discussão pode levar ou não a uma reformulação da teoria. Nesse caso já se estaria passando para a estratégia seguinte de formular teoria.

Em TRAVAGLIA (1996, p. 217), demos um exemplo valendonos da definição tradicional de artigo, ${ }^{21}$ encontrada em gramáticas e livros didáticos. Esse exemplo mostra o tipo de crítica que se pode fazer: a definição de artigo geralmente posta nas gramáticas tradicionais não permite, de modo algum, chegar à lista de duas palavras que pertenceriam a esta classe de palavras: o e $u m$, com as respectivas flexões em número e gênero (os, $a$, as; uns, uma, umas). Na verdade, a definição dada é mais uma definição de determinante do sintagma nominal, no sentido saussureano de determinante, exceto pelo fato de se dizer que o artigo indica o gênero e o número do substantivo, o que exclui determinantes locucionais do tipo que aparece em sintagmas como "mesa de pedra", "limpeza da casa", "livro de Antônio". O que se constata é que as pessoas classificam $o$ e um e suas flexões como artigo pela lista de componentes da classe artigo que é fornecida e não pela definição. Muitas críticas à gramática tradicional podem ser encontradas em trabalhos diversos (tais como: BECHARA, 1985, FERREIRA, 1986, HAUY, 1983, LUFT, 1985, PERINI, 1978, 1985, 1989, 1995), mas não é só a teoria gramatical ou lingüística tradicional que apresenta problemas.

A seguir damos dois exemplos de críticas que podem ser feitas a teorias existentes. O primeiro deles (13) evidencia para o aluno que a forma aceita pela gramática normativa como pertencente à norma culta (como correta, no modo de dizer tradicional de se trabalhar com a gramática normativa) (13.1.a), não é lingüisticamente melhor que a outra, classificada como "incorreta" (ou seja, não própria da norma culta) (13.1.b).

(13) O professor daria uma atividade, constituída pelos seguintes passos:

1) Apresentar aos alunos as duas seqüências lingüísticas abaixo, como textos usados por pessoas para se referir ao mesmo fato e perguntar qual das duas é melhor e por quê. 
a) Os meninos levados quebraram a janela.

b) Os menino levado quebrô a janela.

2) Provavelmente surgirão respostas condicionadas pelo ensino normativo de que o texto $a$ é melhor porque está "certo" (atende às regras da norma culta), enquanto $b$ não é bom porque está "errado", uma vez que não faz a concordância (não atende às regras da norma culta).

3) Nesse momento o professor deve perguntar qual é objetivamente a diferença lingüística, de forma, entre os dois textos. Os alunos deverão perceber que em $a$ o produtor do texto colocou a marca ${ }^{22}$ de plural em todos os componentes do sintagma nominal "os meninos levados" e também no verbo "quebraram", enquanto em $b$ o produtor só colocou a marca de plural no primeiro elemento do sintagma nominal "Os menino levado".

4) A seguir deve-se perguntar aos alunos: o que faz uma marca de plural num texto? Qual é sua função? Por que usamos uma marca de plural ao dizer (oralmente ou por escrito) alguma coisa? A conclusão deverá ser que a flexão de número, como o próprio nome indica, é para indicar a quantidade (singular: um, plural: mais de um) de entidades (no caso "menino") de que se está falando.

5) O próximo passo é perguntar aos alunos se, quanto à indicação da quantidade (número) de meninos, há alguma diferença entre os dois textos, ou seja, se do ponto de vista do que se quer dizer, um texto diz coisas que o outro não diz. A resposta obviamente será que não, pois os dois textos indicam que se está falando de mais de um menino, um grupo de meninos que fizeram a ação de quebrar uma determinada janela. Contudo há uma diferença: o texto $a$ dá a informação sobre a quantidade de meninos quatro vezes, enquanto o texto b só o faz uma vez, logo no seu início. Aliás, nesse momento, o professor pode discutir com os alunos 
o fato de que na língua, falada ou escrita, culta ou não-culta, não se encontram textos como os de $c$, $d$ e $e$ abaixo, em que a indicação do número de meninos não se faz logo no início. ${ }^{23}$ Isto pode ser explicado dizendo que tal ocorre, porque a língua tende a permitir que só se construam as seqüências lingüísticas a serem usadas como textos sempre de forma a facilitar o estabelecimento dos efeitos de sentido pretendidos. Textos como os de $c, d$ e $e$ oferecem dificuldades para o processamento cognitivo, pois o recebedor do texto iria estabelecer, de início, que se fala de um menino apenas e depois teria que retornar e refazer toda a sua leitura, o que não é conveniente na interação, pois geraria problemas diversos e, portanto, não é nada adequado construir os textos com estas formas.

c) *O meninos levado quebrô a janela.

d) *O menino levados quebrô a janela.

e) *O menino levado quebraram a janela.

6) Então, na verdade, por que se tende a dizer que o texto $a$ é melhor em relação a $b$ ? O que se faz é usar um critério (o de atendimento ou não às regras e exigências da norma culta), como se ele fosse o único critério para julgar a qualidade de um texto, de certa forma "apagando" a existência de outros critérios. O professor pode levar o aluno a perceber isso, mostrando-lhe que pode haver outros critérios, ou seja:

a) se o critério for estar ou não de acordo com a norma culta, então o texto $a$ é melhor;

b) se o critério for a veiculação ou não de certas informações, a possibilidade ou não de produzir certos efeitos de sentido, então $a$ e $b$ se equivalem;

c) se o critério for a economia, conseguir o máximo de efeito de sentido com o menor custo expressional possível, então $b$ é melhor, pois $a$ é redundante. 
Obviamente os três critérios acima não são os únicos. Podese pensar outros como, por exemplo: a) critérios estéticos; b) de melhor consideração de determinado público recebedor (como nas publicidades, por exemplo); c) imitar o estilo de alguém; d) ser construído dentro de qualquer variedade dialetal ou de registro da língua, e não só dentro da norma culta (por exemplo, o texto que mais se encaixa num dado dialeto: caipira, feminino, de um grupo social, etc.); e) adequação a um tópico discursivo determinado; f) atendimento da ortografia oficial; e assim por diante.

7) Dessa forma o aluno estará descobrindo os critérios, as intenções, os objetivos e as perspectivas sociais sobre a língua que estão por trás de certas proposições da gramática, nesse caso específico, da gramática normativa, e terá condições de avaliar melhor se o texto que está construindo / construído é adequado ou não para determinada situação. Se é uma situação que exige o uso de norma culta pelas regras sociais de uso da língua, então a será mais adequado, mas em outras circunstâncias ele pode não ser o texto mais conveniente/adequado para ser usado.

Cremos que uma discussão como esta formará um aluno bem mais consciente e, por isto mesmo, com melhores condições: a) de decidir sobre que forma dar a seu texto, de acordo com suas necessidades comunicativas e sociais em dada situação de interação comunicativa; b) de deixar de agir com preconceitos lingüísticos e ser bloqueado por eles (o que seria extremamente pernicioso), como tem acontecido, freqüientemente, em conseqüência de um ensino que, parece-nos, tem sido mais eficiente para inculcar, por meio de equívocos e preconceitos, sentimentos de incompetência do que para desenvolver competência comunicativa. Tudo deve, pois, caminhar para um aprendizado do uso da língua que considere suas variedades (inclusive a norma culta com suas variantes) dentro de um ambiente lingüístico mais variado, eclético, e por que não dizer, mais democrático. 
O exemplo acima é de crítica a posturas da gramática normativa de apresentar uma forma de uso da língua como boa e as outras como ruins e por isso mesmo indesejáveis e até mesmo inadmissíveis. Em (14) tem-se uma amostra de atividade de crítica a teorias descritivas da língua, para desenvolver a capacidade de pensar e de perceber como elas são construídas e são ou não adequadas à descrição que pretendem fazer da língua. Como já dissemos, a percepção de tal adequação ou não-adequação de uma teoria poderá ser usada pelo professor para trabalhar determinada teoria com seu aluno, caso decida, por qualquer razão, ensinar teoria gramatical em suas aulas de língua materna.

(14) A proposta é desenvolver uma atividade de crítica à proposição que a teoria da gramática tradicional tem feito da classe de palavras chamada advérbio. A atividade pode seguir os passos de 1 a 5 especificados abaixo.

\section{Passo 1:}

Inicialmente o professor apresentaria aos alunos ou lhes pediria para buscarem em gramáticas tradicionais e/ou livros didáticos a conceituação de advérbio e as subclasses propostas, com sua respectiva caracterização. Se quiser, ele pode preceder essa tarefa por uma exposição ou discussão de por que (razões ou motivações) (PERINI, 1978, 1985 e 1995) e como (modo: utilizando critérios que podem ser de naturezas diversas, geralmente morfológicos, sintáticos e semânticos) se estabelecem classes de palavras. Isso dependerá do que a turma já sabe, ou não, teoricamente sobre o fato em foco e sobre construção de teorias.

Provavelmente o conteúdo da apresentação ou o resultado da busca seria o seguinte: 


\section{ADVÉRBIO: ${ }^{24}$}

A) Caracterização sintática

1) Advérbio é a expressão modificadora que se refere geralmente ao verbo ou ainda a um adjetivo, a um advérbio ou a uma declaração inteira.

2) Advérbio é a palavra modificadora / determinativa do verbo, mas modifica também adjetivos e mesmo advérbios e frases totais. Serve de determinante ao verbo, ao adjetivo ou a outro advérbio.

3) Advérbio é o adjetivo do verbo.

4) Para MACAMBIRA (1974, p. 42-43) "pertence à classe do advérbio toda palavra invariável que se articula com os advérbios tão, quão ou bem.”. Assim: tão / quão, bem depressa/tarde/ cedo/ perto.

5) Os advérbios podem deslocar-se com certa liberdade na frase, ou seja, apresentam uma certa liberdade de colocação.

B) Caracterização semântica

Segundo as gramáticas o advérbio:

1) Denota / exprime / caracteriza uma circunstância (de lugar, de tempo, de modo, intensidade, condição, negação, dúvida, etc.). Segundo CUNHA (1970, p. 369) expressa uma circunstância ou outra idéia acessória;

2) Expressa uma circunstância do processo verbal, as circunstâncias que cercam a significação verbal ou a intensidade da qualidade dos adjetivos ou reforça outro advérbio;

3) Exprime as seguintes circunstâncias em que se desenvolve o processo verbal:

3.1 - lugar: abaixo, acima, em cima, arriba, algures, alhures, abaixo, avante, em baixo, adiante, atrás, aí, além, ali, acolá, aquém, aqui, através, cá, acá, debaixo, defronte, dentro, detrás, diante, embaixo, fora, junto, lá, longe, onde, aonde, donde, perto, etc. 
Locuções: à direita, à esquerda, à distância, ao lado, de dentro, de cima, de longe, de perto, em cima, para dentro, para onde, por ali, por aqui, por dentro, por fora, por onde, por perto, etc.; 3.2 - tempo: agora, ainda, amanhã, antes, antanho, breve, hoje, ontem, anteontem, já, nunca, enfim, cedo, tarde, jamais, logo, sempre, então, depois, ora, jamais, nunca, outrora, imediatamente, eventualmente, anteriormente, diariamente, etc.;

Locuções: à noite, à tarde, à tardinha, às vezes, de dia, de manhã, de noite, de repente, de vez em quando, de tempos em tempos, em breve, à / pela manhã, etc.

3.3 - modo: assim, adrede, debalde, depressa, devagar, mal, melhor, pior, bem, como e um grande número dos terminados em _ mente (para alguns estudiosos todos): rapidamente, gulosamente, divinamente, suavemente, estupidamente, etc.;

Locuções: a fio, ao natural, à toa, à vontade, à força, ao contrário, ao léu, às avessas, às claras, às direitas, às pressas, às tontas, às escondidas, com gosto, com amor, com prudência, com energia, com brandura, com pressa, de bom grado, de cor, de coração, de propósito, de um golpe, de má vontade, de regra, de viva voz, em mão (= em mãos, usado no sobrescrito de correspondências), em geral, em silêncio, em vão, gota a gota, passo a passo, por acaso, por atacado, por um triz, por acaso, etc.;

3.4 - causa ${ }^{25}$

Locuções: por milagre, por força;

3.5 - assunto;

3.6 - companhia;

3.7 - concessão;

3.8 - condição;

3.9 - conformidade; 
3.10 - dívida: porventura, acaso, talvez, quiçá, possivelmente, provavelmente, etc.;

3.11 -fim;

3.12 - instrumento;

3.13 -intensidade ou intensificação: assaz, bastante, bem, demais, mais, menos, muito, pouco, quanto, quão, quase, tão, tanto, etc;

Locuções: de muito, de pouco, de todo, excessiva-mente, demasiadamente, etc.

3.14 - quantidade: assaz, mais, menos, muito, nada, pouco, bastante, etc.

3.15 -referência;

3.16 - afirmação: sim, certamente, decididamente, realmente, efetivamente, etc.; locuções: por certo, com certeza, sem dúvida

3.17 -negação: não, nunca, jamais, ;

Locuções: de forma alguma, de modo algum/nenhum;

3.18 -interrogativos: por que (causa), como (modo), onde (lugar), quando (temporal);

3.19 - relativos: onde, quanto, como (empregados com antecedente em orações adjetivas) (ver LIMA, 1994, p. 176)

3.20 - ordem: primeiramente, secundariamente, finalmente.

C) Classificação: é feita pela circunstância ou outra idéia acessória que expressam. Assim, tem-se advérbio de tempo, modo, lugar, negação, afirmação, dúvida, intensidade, etc. (veja-se relação em B.3 acima)

D) Caracterização morfológica

1) São palavras invariáveis, não admitem flexão;

2) admitem graduação (indicação de grau);

3) admitem derivação (geralmente para indicar grau): cedinho, pertíssimo, etc. 
E) Formação

1) São palavras simples como: hoje, ontem, amanhã, então, assim, sim, não, bem, mal, talvez (mas muitos resultaram de formas compostas: hac hora $>$ agora), tal vez (indicando tempo) $>$ talvez (indicando dúvida), in tunc $>$ então, hoc die $>$ hoje, ad mane $>$ amanhã (Cf. SAID ALI, 1964, p. 184194 e VILELA \& KOCH, 2001, p. 245);

2) Com freqüência, têm a forma de locuções, ou seja, duas ou mais palavras funcionando como advérbio, geralmente com a forma preposição + substantivo (para alguns estudiosos também adjetivo ou advérbio) + (adjetivo): de repente, às cegas, às pressas, à toa, à vista, de caso pensado;

3) Um grande número de advérbios é formado por adjetivo (no feminino ou forma comum aos dois gêneros) + _ mente: intensamente, rapidamente, estupidamente, cortesmente, graciosamente, erradamente, infelizmente, certamente, etc.;

4) Às vezes resultam da adverbialização de um adjetivo na forma do masculino ou, como preferem alguns autores, do neutro, (cf. exs. 14.1)
(14.1) a - João fala muito alto.
b - Eles se vestem jovem.
c - Apesar do calor e do barulho eu durmo tranqüilo.

F) Natureza. Os advérbios podem ter naturezas diversas:

1) Nominal: seriam os advérbios que pela sua origem e significação se prendem a nomes ou os formados de adjetivos acrescidos do sufixo - mente (BECHARA, 1973, p. 153)

2) Pronominal: seriam os advérbios que pela sua origem e significação se prendem a pronomes (BECHARA, 1973, p. 153).

G) Palavras denotativas ${ }^{26}$

Geralmente, no capítulo dos advérbios, algumas gramáticas referem-se a palavras de difícil classificação e, alegando atender à N.G.B, as chamam de palavras ou partículas denotativas de: 
1) inclusão: também, até, mesmo, inclusive, etc.

2) exclusão: só, somente, salvo, senão, apenas, exclusive, etc.

3) situação: mas, então, pois, afinal, agora, etc. (cf. exs. 14.2) 27 $^{27}$

(14.2) a- Mas que felicidade.

b- Então duvida que se falasse latim?

c- Pois não é que ele veio?

4) Retificação: aliás, melhor, ou melhor, isto é, ou antes, etc.

5) Designação: eis

6) Realce: é que, cá, lá, só, etc.

7) Expletivo: lá, só, ora, que, etc.

8) Explicação: a saber, por exemplo, isto é, como, etc.

9) Avaliação: quase, mais ou menos, etc.

Os passos seguintes serão de discussão com os alunos de pontos problemáticos na teoria levantada sobre os advérbios e que pode ser feita na ordem em que o professor desejar ou à medida que os pontos forem sendo levantados pelos alunos. O que temos indicado como passos a seguir é mais um lembrete de pontos que poderiam ser discutidos na crítica da teoria acima.

\section{Passo 2: Discussão de problemas na caracterização sintática}

2.1 - Geralmente se define o advérbio como um modificador ou determinante do verbo, como uma espécie de adjetivo do verbo. Mas essa parte da definição é problemática. O que é ser um modificador? O que é ser um determinante do verbo? Quanto à questão do modificador, podemos lembrar os comentários de PERINI (1995, p. 340-342), que, discutindo essa mesma questão do advérbio, diz que a noção de modificação é obscura e se caracteriza por um misto de semântica e sintaxe. Semanticamente poder-se-ia dizer que o advérbio teria seu significado amalgamado ao de um outro elemento, formando um todo semanticamente integrado e diferente do elemento 
sem advérbio. Perini exemplifica com a oposição entre corremos X corremos depressa (em que depressa seria um advérbio). Do ponto de vista sintático, modificar referir-se-ia à "ocorrência conjunta dentro de um constituinte: o que se chama em sintaxe estar em construção com." Então em corremos depressa corremos está em construção com depressa e este seria então um advérbio. No sentido sintático, portanto, modificar equivale, mais ou menos, a determinante, que é usado por alguns estudiosos no lugar de modificador. Seria o determinante em um sintagma no sentido saussureano. Todavia isso não é suficiente para definir, distinguir e identificar o advérbio pois, nos exemplos de (14.3), os elementos em itálico inegavelmente podem ser vistos como modificadores e/ou determinantes de um verbo, como estando em construção com um verbo e, em nenhum estudo lingüístico, se admite que eles sejam advérbios. Tradicionalmente, seriam substantivos/nomes funcionando como complementos do verbo (objeto direto e indireto). Como esses termos são modificadores de verbos, ou se admite que são advérbios ou se modifica a definição de advérbio.

\section{(14.3) a - João fez uma cadeira. \\ b - Nós demos um presente para eles.}

2.2 - Por outro lado, encontramos construções em que palavras que constam da lista dos advérbios em todas as gramáticas não aparecem como modificadoras e/ou determinantes do verbo ou qualquer outra classe, mas como determinadas. É o que acontece nos exemplos de (14.4.a, b) em que os elementos em itálico são "advérbios" funcionando como sujeitos das frases. Ou advérbios não são só modificadores / determinantes, ou essas palavras não são advérbios e devem ser excluídas da lista dos componentes dessa classe de palavra, ou a definição de advérbio tem que ser modificada para contemplar este comportamento de hoje e amanhã. Em (14.4.c) o "advérbio" 
amanhã aparece como determinante do verbo, mas funcionando como complemento (objeto indireto?).

(14.4) a - Hoje é segunda-feira.

b - Amanhã será outro dia.

c - Quero saber do amanhã.

Pode-se argumentar que esses advérbios, assim como outros, podem exercer funções como sujeito e complemento verbal devido a sua natureza nominal (veja passo 1, letra F e MACAMBIRA, 1976). Isso é verdade, mas não resolve o problema da definição do que seja "advérbio".

2.3 - Dizer que o advérbio modifica o advérbio é circular, porque se pressupõe que já se saiba o que é advérbio para definir o que é advérbio. Portanto este aspecto da definição que diz que o advérbio modifica / determina / acompanha um advérbio não possui nenhuma eficiência descritiva.

2.4 - A definição do advérbio como a classe de palavras que modifica o verbo, o adjetivo e o próprio advérbio, não abrange o total comportamento sintático de modificador ou determinante das palavras que geralmente são incluídas nessa classe. Muitos autores reconhecem que certas palavras chamadas de advérbio podem referir-se a um substantivo (BUENO, 1968, p. 150, VILELA \& KOCH, 2001, p. 244-245) (cf. exemplos 14.5), a um pronome (MACAMBIRA, 1974, p. 43-44) (cf. exemplos 14.6), a um numeral (MACAMBIRA, 1974, p. 43-44) ${ }^{28}$ (cf. exemplos 14.7), a uma preposição (MACAMBIRA, 1974, p. 44) (cf. exemplos 14.8), a uma conjunção (MACAMBIRA, 1974, p. 44) (cf. exemplos 14.9) e mesmo a todo o predicado ${ }^{29}$ (cf. exemplos 14.10), a toda uma oração ou frase ${ }^{30}$ (BECHARA, 1973, p. 152, CUNHA, 1970, p. 368, MACAMBIRA, 1974, p. 44-45, VILELA \& KOCH, 2001, p. 244-246) (cf. exemplos 14.11) e à própria enunciação (VILELA \& KOCH, 2001, p. 244-246) (cf. exemplos 14.12). Portanto só não seriam modificados pelo advérbio o artigo e a interjeição da classificação tradicional. 
(14.5) a - Se ele é muito homem, também ela é muito mulher.

b - Só Deus pode te ajudar.

c - Homens assim merecem toda a nossa consideração.

d - A citação abaixo não deixa dúvidas.

Numa frase como (14.5.a), poder-se-ia contra-argumentar que advérbio não está modificando / determinando um substantivo, mas um substantivo adjetivado. Este contra-argumento pressupõe a aceitação da derivação imprópria, ou seja, que uma palavra pode mudar de classe. Nem todos aceitam este fato (Cf. PERINI, 1995, caps. 12 e 13). Todavia esse contraargumento não se aplicaria a (14.5.b-d), pois "Deus", "Homens" e "citação" não podem ser vistos como estando adjetivados.

(14.6) a - Ele aqui me emprestou uma caneta.

b - Ninguém mais me procurou.

(14.7) a - João apresentou uns poucos três exemplos

b - - Quantos parafusos você quer? - Mais cinco.

No caso dos numerais pode-se contra-argumentar que o advérbio não modifica o numeral em si, mas o sintagma nominal como um todo (numeral + substantivo), mesmo que o substantivo esteja elíptico, como em (14.7.b). Todavia permanece o problema para a definição de advérbio como modificador / determinante apenas dos verbos, adjetivos e advérbios.

(14.8) a - O pássaro voava exatamente sobre a cabeça do menino.

b - Chegou muito após o início da festa.

(14.9) a - Aborreço este lugar somente porque é muito barulhento.

b - Fechou a porta pouco antes que o ladrão viesse 
No caso das preposições e conjunções pode-se contra argumentar, dizendo que o advérbio se refere não apenas à preposição e à conjunção, mas a toda a expressão que elas iniciam ou introduzem. MACAMBIRA (1974, p. 44-45), usando argumentos de Nesfield, rebate este contra-argumento. Todavia, mesmo que a referência seja ao sintagma preposicionado ou à oração iniciados pela preposição ou conjunção, permanece o problema na caracterização do "advérbio".

(14.10) a - Maria convidou-me para a festa ontem.

b - Sua família vai morar tranqüilamente aqui.

$\mathrm{c}$ - Recentemente o Brasil assinou um tratado comercial vantajoso com a União Européia

(14.11) a - Felizmente ela não veio à festa.

b - Talvez ele esteja doente

c - Lamentavelmente você não poderia viajar conosco.

d - Realmente, este rapaz é meu irmão mais novo.

(14.12) a - Teoricamente podemos dizer que este tipo de texto existe.

b - Estupidamente, Maria confessou o que não fez.

Cremos que quase todos os "advérbios" que modificam a frase inteira (14.11 e 14.12) são também advérbios da enunciação, mas nem todos têm a mesma função (Cf. VILELA \& KOCH, 2001, p. 248-253).

2.4 - Diversos trabalhos dizem que o advérbio que modifica o adjetivo ou o advérbio é tão somente o de intensidade (BUENO, 1968, p. 147, CUNHA, 1970, p. 368, LIMA, 1994, p. 174, VILELA \& KOCH, 2001, p. 249) (cf. os exemplos de 14.13). Na verdade, os advérbios de intensidade parece que só modificam adjetivos e advérbios, numa espécie de marcação de grau. Por essas razões, pode-se questionar se os "advérbios" de intensidade não constituiriam uma subclasse especial dos advérbios ou se 
não seriam uma outra classe de palavras (os intensificadores) como propõe PERINI (1995, cap. 13). Se se admitir essa nova classe de palavras (os intensificadores), os tradicionais "advérbios" deixariam de ser definidos como modificadores de adjetivos e advérbios.

(14.13) a - A atriz representou divinamente bem.

b - Este rapaz escreve muito bem.

c - Tereza, muito inteligentemente, não disse sua opinião.

d - Ele foi muito/bem desleal.

e - Na verdade ele é quase bonito.

Quanto à afirmação de que adjetivos e advérbios só são modificados por advérbios de intensidade, é preciso considerar casos como o de (14.13.a), em que o advérbio divinamente é que modifica o advérbio bem. Pode-se dizer que divinamente é um intensificador?

2.5 - Como vimos no item A.4 da caracterização dos advérbios no passo 1, MACAMBIRA (1974, p. 42-43) propõe que "pertence à classe do advérbio toda palavra invariável que se articula com os advérbios tão, quão ou bem.”. Assim: tão / quão, bem depressa/ tarde/ cedo/ perto. Essa caracterização apresenta problemas pelo menos por duas razões:

a) pressupõe saber que tão, quão e bem são advérbios para se definir advérbio;

b) como reconhece o próprio Macambira, aqui, ali e acolá só se articulam com bem: bem aqui/ali/acolá, mas não com tão ou quão. Nesse caso eles são ou não advérbios, já que integram a lista de advérbios de lugar em todas as gramáticas? Haveria outros "advérbios" que não se articulam com esses advérbios? Considere-se, por exemplo, aí, algures, albures: é possível dizer quão / tão aí, quão / tão / bem algures, albures?; 
Parece, pois, que a observação quanto ao tipo de elemento modificado pelo advérbio e para o qual o advérbio serve de determinante é pouco pertinente para identificar os componentes dessa classe de palavras tal como ela tem sido configurada. Tendo em vista esses problemas, alguns autores têm proposto caracterizações semânticas do "advérbio", para impedir, por exemplo, que se tenha que dizer que complementos verbais (como o objeto direto e indireto: cf. ex. 14.3 em 2.1) são advérbios. A questão semântica na caracterização do "advérbio" vem discutida no passo 3.

2.6 - Questões sobre a colocação dos advérbios

1) Como vimos na caracterização sintática dos "advérbios", quase todos os gramáticos dizem que esta é uma classe de palavras que tem uma grande mobilidade na frase, podendo deslocar-se com certa liberdade na mesma, ou seja, apresenta grande liberdade de colocação. Essa propriedade, porém, não se aplica a todas as palavras tradicionalmente incluídas na classe dos advérbios e muitos estudos, mesmo tradicionais, têm mostrado esse fato. CUNHA (1970, p. 371), por exemplo, faz afirmações sobre a colocação dos advérbios (como as de a a $c$ abaixo), que já evidenciam que a liberdade de colocação é limitada em muitos casos. Podemos acatar a proposta desse gramático (ou as de outros estudiosos) ou observar por nós mesmos, a partir de dados, se a hipótese de liberdade de colocação dos advérbios vale para todos ou somente para alguns deles. A aceitação da hipótese como um critério para circunscrever essa classe de palavras implica aceitar que alguns elementos nela costumeiramente incluídos não seriam advérbios.

Fatos como os abaixo, que mostram que a hipótese de liberdade de colocação dos advérbios parece não valer para todos os "advérbios", exigem que se reflita 
melhor sobre a hipótese da liberdade de colocação dos advérbios, como critério definidor e distintivo dos mesmos se tal classe existir:

a) Os advérbios modificadores de adjetivos, particípios isolados ou outros advérbios colocam-se de regra antes deles;

b) Para os advérbios modificadores de verbo observase:

- que os de modo geralmente colocam-se depois do verbo;

- os de tempo e de lugar podem colocar-se antes ou depois do verbo;

- o realce do advérbio é conseguido de regra por sua antecipação ao verbo, o que sugere que a posição não-marcada é a posterior ao verbo;

c) Os advérbios modificadores de frase inteira são colocados no início ou no final da frase, mas não no meio da mesma. Essa posição é rara e só possível para alguns advérbios e assim mesmo pode haver variações de sentido. Em qualquer posição ele vem geralmente isolado por pausas;

d) Além do mais, a liberdade de colocação não é tão grande, uma vez que a mudança de posição quase sempre acarreta mudanças de sentido. Minimamente o advérbio deslocado ganha um certo realce ou destaque (veja exemplos 14.14-16). Em (14.14) $a$ e $b$, o escopo dos advérbios é a frase inteira, significando que o falante considera o fato de Maria confessar o que não fez uma estupidez da parte dela. A frase $b$ parece não ser muito boa nesta acepção e ser ambígua numa certa medida, podendo ter também a acepção de $c$. Já em $c$ o advérbio estupidamente é um advérbio de modo cujo escopo é apenas o verbo confessar. Em (14.15) o advérbio ontem posposto seria enfático, 
porque, para alguns estudos, a ordem não-marcada seria aquela em que o advérbio fica à esquerda da sentença. Em (14.16), para as duas posições, temos duas interpretações possíveis. $\mathrm{Na}$ primeira, temos um advérbio de enunciação, em que o produtor do texto diz que, para ser honesto consigo e com seus interlocutores, ele tem de reconhecer que a pessoa indicada por "ele", foi capaz de conquistar os eleitores. Na segunda, o sentido é de que "ele" conquistou os eleitores porque foi honesto em sua fala. A primeira interpretação é preferencial em $b$ e a segunda, em $a$. Em (14.17), o escopo do "advérbio" só se modifica de acordo com sua posição e o sentido do texto muda: em $a$, o escopo é João; em $b$, é o predicado (veio à reunião); em $c$, é o determinante do verbo (à reunião); em $d$, só não incide sobre o verbo e indica o modo como ele veio significando sozinho. Nestas condições pode-se falar em liberdade de colocação, como se nada acontecesse ao mudar a colocação?

(14.14) a- Estupidamente, Maria confessou o que não fez.

b- Maria confessou o que não fez, estupidamente.

c- Maria confessou estupidamente o que não fez.

(14.15) a- Seus amigos me visitaram ontem.

b- Ontem seus amigos me visitaram.

(14.16) a- Falando bonestamente ele conquistou os eleitores.

b- Honestamente falando ele conquistou os eleitores.

(14.17) a- Só João veio à reunião.

a) João só veio à reunião.

b) João veio só à reunião.

c) João veio à reunião só. 


\section{Passo 3: Problemas na caracterização morfológica}

3.1 - Quando se percorre a relação dos elementos componentes da classe de palavras "advérbio", observa-se que se incluem, na exemplificação, sintagmas que não constituem uma palavra, nem uma locução (esta pode ser vista como uma palavra composta). O critério para saber se se tem uma palavra (simples ou composta) pode ser, por exemplo, o fato de estar dicionarizada ou a intuição dos falantes que percebem uma seqüência lingüística como uma palavra composta ou como uma construção (sintagma adverbial?) que não é nem uma palavra simples, nem uma palavra composta (locução). ${ }^{31} \mathrm{O}$ leitor pode se perguntar se aceita como advérbios os elementos em itálico nos exemplos de (14.18), todos retirados de BECHARA (1973, p. 152-153). Entre parênteses indicamos a circunstância que expressam, segundo o mesmo autor. Do nosso ponto de vista, dificilmente se pode dizer que os elementos em itálico sejam componentes de uma classe de palavras, pelo menos se quisermos fazer valer a oposição entre palavra e construção.

(14.18) a- Conversar sobre música. (assunto)

b - Morrer de fome. (causa)

c - Sair com os amigos. (companhia)

d - Voltaram apesar do escuro. (concessão)

e - Só entrará com autorização. (condição)

f - Fez a casa conforme a planta. (conformidade)

g - Preparou-se para o baile. (fim)

$\mathrm{h}$ - Escrever com lápis. (instrumento)

i - Passou pela cidade. (lugar)

j - "O que nos sobra em glória de ousados e venturosos navegantes, míngua-nos em fama de enérgicos e previdentes colonizadores" (LATINO COELHO) (referência). 
No mesmo caso estariam, para nossa intuição de falantes, algumas locuções listadas pelas gramáticas tais como: com gosto/ amor / ódio / deprezo/preguiça / prudência, em trechos como os de (14.19).

(14.19) a - O cunhado tratou-o com ódio / desprezo / amor. (modo)

b - Nós fizemos tudo com amor/preguiça/prudência. (modo)

3.2 - Algumas locuções adverbiais não se encaixam no modelo de construção das mesmas proposto pelas gramáticas: preposição + substantivo (adjetivo? advérbio?) + (adjetivo). Este é o caso por exemplo da locução "adverbial" de modo "à queima roupa". Deve-se mudar o esquema de constituição das locuções para incluir tais casos?

\section{Passo 4: Problemas na caracterização semântica}

4.1 - O critério semântico poderia ser usado para resolver os problemas não solucionados pelos critérios sintáticos e morfológicos. A caracterização semântica básica diz que o "advérbio" expressa circunstância do processo verbal, as circunstâncias que cercam a significação verbal ou a intensidade da qualidade dos adjetivos ou reforça outro advérbio. Para CUNHA (1970, p. 369), expressa circunstância ou outra idéia acessória.

Em primeiro lugar é preciso discutir o fato de que temos um valor para os advérbios que acompanham verbos (exprimem circunstâncias) e outro para os que acompanham adjetivo e advérbio (exprimem intensidade). Se intensidade / reforço não são circunstâncias, trata-se realmente da mesma classe ou são duas classes distintas? Se são duas classes distintas, por que chamar ambas de advérbio como se fossem uma só? Ou há algo que justifica reuni-las em uma única classe? Se for esse o caso, o que justifica esta união se não é nem o que elas expressam, nem o elemento de que elas são determinantes? Além disso, 
os advérbios determinantes de outras classes e construções (substantivos, preposições, conjunções, numerais, sintagmas, orações, enunciação) expressam o quê? Circunstâncias? Ou não são advérbios como a gramática diz? Todas estas questões revelam problemas da teoria sobre os advérbios.

Em segundo lugar pode-se perguntar se a idéia acessória a que CUNHA (1970) se refere é ou não do processo verbal ou se com isso Cunha queria referir-se aos significados de intensificação da qualidade do adjetivo e reforço do advérbio. Se não for a intensidade e o reforço o que seria então? A expressão "idéia acessória" é por si muito vaga e pode incluir os mais variados conteúdos expressos pela língua. Além disso, o que se quis dizer com "acessória" em "idéia acessória”? Pecase pela não-definição e explicação dos termos usados.

Do mesmo modo pode-se perguntar: o que é circunstância? MACAMBIRA (1974, p. 43) diz que o termo circunstância é muito vago e não tem, por isso, muita valia na definição do que seja advérbio. Se listarmos as circunstâncias (tempo, modo, lugar, etc.) não se apresenta uma definição de advérbio, porque saberíamos quais são as circunstâncias, mas não o que é circunstância. Aliás, os gramáticos geralmente fazem isso dizendo que as circunstâncias são: tempo, modo, lugar, etc., sem se preocupar em fazer uma lista mais completa do que se incluiria nas circunstâncias. Todavia, sem um conceito claro e preciso de circunstância, ficamos com o problema de saber se determinadas noções não-constantes da lista são ou não circunstâncias, já que não sabemos o que é circunstância. Podese também concordar com Macambira, quando afirma que dizer que circunstância são coisas como lugar e tempo, pode levar ao problema de decidir se sertão, cidade e passado, hora são ou não advérbios.

Discutindo a definição de advérbio, já perguntamos a centenas de professores brasileiros o que é "circunstância". Até hoje nenhum soube nos dizer o que é circunstância, apesar de 
todos declararem (ou devo dizer confessarem?) que já deram essa definição de advérbio para seus alunos. Todos havemos de concordar que foi muita sorte nenhum aluno fazer-nos essa pergunta, não é mesmo?

O dicionário de HOUAISS \& VILLAR (2001) no verbete circunstância registra onze sentidos básicos. Destes alguns aparentemente, num primeiro momento, seriam pertinentes para a conceituação de advérbio, tanto que aparecem, em parte, nas gramáticas: 1 - condição de tempo, lugar ou modo que cerca ou acompanha um fato ou uma situação e que lhes é essencial à natureza (a presença da luz é circunstância indispensável para a determinação das cores); 2 - fato acessório ou outro pormenor que se prende a um acontecimento ou a uma situação; particularidade ( idade é circunstância secundária, desde que haja competência); 4 - o conjunto de fatores materiais ou não que acompanham ou circundam alguém ou alguma coisa; contexto, mundo; 6 - conjuntura, momento, ocasião. Etimologicamente vem do latim circumstantia, ae (ação de estar ao redor) e circumstare (conservar-se ou estar ao redor).

Como se pode perceber, o que os dicionários dizem não ajuda muito, pois considera-se como circunstância tudo o que está em volta de, ao redor de ou acompanha um fato, uma situação, seja essencial à sua natureza ou simplesmente acessório, uma particularidade, enfim tudo o que compõe o contexto de ocorrência do fato ou situação. Isto pode ser muito amplo e levar a incluir muita coisa nas circunstâncias. Por exemplo, em (14.20) os pormenores ou detalhes materiais de o gato ser enorme e pintado e de a janela ser de aluminio e a condição de eu estar distraído são ou não circunstâncias da situação de aparecimento do gato?

(14.20) Estava eu distraído quando um enorme gato pintado apareceu na janela de alumínio.

Se formos à lista dos tipos de advérbio apresentada no passo 1 e se abstrairmos a discussão quanto à classificação das 
"partículas denotativas" (são ou não advérbios?), pode-se discutir se muitas das "circunstâncias" (?) ali arroladas são ou não circunstâncias. Tendo em vista os conceitos de circunstância apresentados, pode-se perguntar se as noções abaixo seriam circunstâncias do fato ou situação expresso(a) pelo verbo:

a) a afirmação ou negação de um fato ou a dúvida sobre ele. Eles não estão em redor do fato, como um contexto, mas são um julgamento de valor de verdade em relação à realização ou não de algo no mundo real;

b) a indicação de atitudes do falante em relação ao que diz:

- pareceres subjetivos (felizmente, infelizmente, lamentavelmente);

- valores modais: certeza (certamente, realmente, efetivamente); possibilidade (possivelmente), probabilidade (provavelmente);

c) a causa, a condição e o fim. Na verdade, causa, condição e fim parecem estar mais relacionados à geração de fatos e situações;

d) o assunto. Parece-nos que este é, na verdade, o objeto do dizer. Note-se que esse tipo de "adjunto adverbial" aparece com verbo de elocução (falar, dizer, perguntar, responder, escrever, etc.);

e) a ordem. Há evidências de que os "advérbios" de ordem indicam a ordenação de vários fatos entre si no tempo cronológico da realidade e/ou no texto (no tempo do texto);

f) a designação, a referência, a inclusão, a exclusão, a quantidade. Na verdade, todas as palavras que veiculam essas noções realizam, com funções diversas, certos tipos de indicação sobre entidades presentes nos textos tais como: apresentar (uma espécie de apontar) em presença uma entidade já referida textualmente em ausência (designação); lembrar uma entidade (referência); incluir ou excluir uma entidade (inclusão e exclusão); indicar quantidades de uma 
entidade (quantidade). A indicação de quantidade de uma entidade não é feita só por "advérbios", mas por muitos outros recursos da língua (numerais, flexão de número, adjetivos, substantivos, etc.). ${ }^{32}$ Nesse caso, por que esses outros recursos não são classificados de advérbios?

g) a concessão, a conformidade, a retificação, o realce, a explicação e a avaliação. Aqui parece que se tem, na verdade, não uma indicação de circunstância, mas, antes, estratégias argumentativas do falante em relação ao dizer de um estado de coisas na sua correlação com outro estado de coisas, sendo que este segundo pode estar ou não explícito no texto;

h) parece que a intensidade já fica descartada da lista das circunstâncias quando na própria definição de advérbio se diz que ela se refere à qualidade do adjetivo ou ao próprio advérbio.

Se todas essas noções não forem circunstâncias e se o advérbio for definido por exprimir circunstância, então poderse-ia classificar as palavras que exprimem tais noções como advérbios?

Embora outros questionamentos sejam possíveis, ${ }^{33}$ cremos que o que se disse até aqui seja suficiente para deixar claro que uma teoria que sustenta que a classe dos advérbios é constituída pelas palavras que indicam circunstância, apresenta problemas. Primeiro devido à dificuldade de definir o que seja circunstância e segundo quando se observa, em confronto com uma tentativa de definir circunstância, a lista de circunstâncias que tem sido normalmente apresentada.

4.2 - Para muitas "circunstâncias" as gramáticas não listam advérbios: assunto, companhia, concessão, condição, conformidade, fim, instrumento, referência (cf. a listagem do passo 1, item B.3). Os exemplos dados para essas circunstâncias e que transcrevemos em (14.17) são, na verdade, exemplos de sintagmas preposicionados (construções) e não propriamente 
de palavras ou locuções classificáveis como pertencentes a uma classe de palavras (no caso a dos advérbios). Assim sendo, pode-se questionar e discutir se a indicação de circunstância é exclusiva dos advérbios e por isso definidora dos mesmos, ou se eles são apenas um dos recursos disponíveis na língua para tal. Neste segundo caso, expressar circunstância não seria traço suficiente para caracterizar a classe dos advérbios em oposição a outros elementos da língua.

4.3 - Do ponto de vista da significação dos advérbios, há alguns fatos que devem ser observados, pois criam problemas para a classificação dos advérbios, se esta for feita pela circunstância que eles indicam:

a) Alguns advérbios classificados como de tempo seriam de freqüência: uma vez, duas vezes, sempre, às vezes. Assim sendo, sua classificação seria como de tempo ou como de freqüência?

b) Alguns expressam simultaneamente mais de uma circunstância. Desse ponto de vista seriam híbridos: nunca, jamais, (tempo e negação). Nesse caso teriam duas classificações ou só uma (por exemplo, a da circunstância predominante, se isso existir)?

c) Outros advérbios podem ter ora um valor ora outro, aparentemente conforme o contexto de uso (Cf. exemplos 14.21-23). Nesse caso é um advérbio só ou são dois advérbios homônimos?

(14.21) a - Este rapaz canta muito mal. (modo)

b - Mal chegou da viagem e foi trabalhar. (tempo)

(14.22) a - Ele desempenhou bem o seu papel na peça. (modo)

b - Este seu irmão é bem atrevido. (intensidade)

(14.23) a - Este lugar ficou muito frio. (intensidade)

b - Eles venderam muita carne. (quantidade) 


\section{Passo 5: Outras questões}

5.1 - As palavras denotativas são ou não advérbios? Muitas funcionam como operadores argumentativos. Esse papel (função) textual-discursivo seria o critério para propor uma classe de palavras, que, como já dissemos, incluiria também muitas das chamadas conjunções e outros conectores. Alguns autores incluem explicitamente nos advérbios parte dessas "partículas", outros o fazem implicitamente ao dar listas e/ou exemplos de advérbios. Se, como se propôs para a N.G.B., são palavras de difícil classificação, podem ser classificadas dentro das dez classes tradicionais? Se sim, por que não o fazemos? Por dificuldade ou incompetência para aplicar os critérios classificatórios? Se não, deve-se propor outra(s) classe(s) de palavra(s)? Neste caso qual (quais)? Veja-se também o que dissemos em 3.1 sobre expressar ou não circunstância.

5.2 - Muitos gramáticos dizem que, às vezes, os advérbios resultam da adverbialização de um adjetivo na forma do masculino ou, como preferem alguns autores, do neutro (cf. exs. 14.24).
(14.24) a - João fala muito alto.
b - Eles se vestem jovem.
c - Apesar do calor e do barulho eu durmo tranqüilo.

A questão aqui é saber se existe adverbialização de adjetivos. Embora muitos autores falem tranqüilamente em adverbialização de adjetivos (e outras mudanças de classe), outros autores (cf. PERINI, 1995) não aceitam a mudança de classe. Estes acham que teoricamente é melhor aceitar que uma palavra tem a possibilidade de exercer duas ou mais funções ou papéis sintáticos, o que as faria pertencer a classes distintas daquelas que só podem exercer uma função. Nesse caso, então advérbio é uma classe de palavras ou uma função como propõe CÂMARA JÚNIOR (1970)? De qualquer maneira o que é advérbio está mal definido ou a lista de advérbios não está 
bem feita, porque Câmara Júnior diz que o advérbio é determinante do verbo, mas, como vimos, tem-se colocado na lista dos advérbios determinantes de outras coisas que não o verbo.

5.3 - Algumas palavras listadas como advérbios aparecem, no mesmo autor, também em listas de outras classes de palavras e com o mesmo valor semântico: pronomes (muito, pouco, quanto, nada, onde, como, nada), conjunção (ora, porque, quando); interjeição (avante). Como distinguir se são de uma classe ou de outra, já que a significação (circunstância) é a mesma? Por serem modificadores / determinantes de elementos de natureza diferente? (Cf. 14.25, por exemplo). Ou por outro critério qualquer? Neste caso, qual? (Cf. abaixo o comentário de 5.4). Ou seja, a questão básica é: temos duas palavras homônimas que integram classes diferentes ou temos uma palavra só com comportamentos típicos de duas classes de palavras distintas?

(14.25) a - A menina está muito triste. (intensidade) (modifica adjetivo)

b - Eles pescaram muito peixe. (quantidade) (modifica substantivo)

c - Eu te amo muito, minha filha. (intensidade/ quantidade) (modifica verbo)

5.4 - No que diz respeito à proposição de advérbios relativos e interrogativos é preciso observar que, embora nas gramáticas estejam alinhados na mesma classificação baseada nas circunstâncias, funcionar como relativo ou interrogativo nada tem a ver com a indicação de circunstâncias, tanto que as gramáticas fazem a lista dos advérbios destes dois tipos especificando entre parênteses a circunstância que expressam:

a) interrogativos: por que (causa), como (modo), onde (lugar), quando (tempo);

b) relativos: onde (lugar), quando (tempo), como (modo). 
Os interrogativos são assim chamados por estarem sendo usados em uma pergunta em que se quer saber a causa, ou o tempo, ou o lugar ou o modo de ocorrência de algo. BUENO (1968, p. 148) não aceita que se fale em advérbios interrogativos, considerando que a frase é que é interrogativa e não o advérbio, que seria de causa, modo, lugar ou tempo. Os relativos são assim considerados porque ligam duas orações e porque, na oração que o relativo inicia, ele fica no lugar de um nome da oração antecedente e funciona como um adjunto adverbial, sendo por isso considerado um advérbio. Evidentemente, a inclusão desses interrogativos e relativos na classe dos advérbios por alguns gramáticos é feita pelo fato de eles indicarem circunstância, o que justifica o questionamento feito quanto ao fato de ter ou não que se incluir na classe dos advérbios todas as palavras que expressam tempo, modo, lugar, causa, dúvida, afirmação, intensidade, etc. (circunstâncias?) (cf. acima o comentário de 5.3)

Esperamos que os exemplos dados sejam boas sugestões no sentido de deixarem claro, de modo bem concreto: a) o que se pode fazer em atividades de crítica a teorias; b) e também como tais atividades podem contribuir para a formação no aluno das habilidades de pensar, de raciocinar, de construir conhecimentos ou utilizá-los de modo consciente, com independência intelectual. Evita-se, assim, que o aluno seja um mero repetidor de hipóteses e teorias sem perceber que, quase sempre, elas têm problemas, falhas e que não são a verdade absoluta, nem a única possibilidade para a descrição e explicação de fatos e fenômenos do mundo natural e social. Isso se aplica às descrições e explicações científicas, mas também, e com mais razão, ao conhecimento comum que mais freqüentemente não tem parâmetros ou métodos para sua constituição e pode, mais que o científico, ser vitimado por deturpações advindas de vieses de ideologias de qualquer natureza (religiosa, política, etc.), preconceitos, interesses particulares ou de grupos e outros problemas, afastando-se muito da realidade. 


\subsubsection{3 - Criar, formular teorias}

Este tipo de estratégia é altamente desejável, pois permite que o aluno discuta pressupostos teóricos, hipóteses descritivas e explicativas e sua adequação aos dados, e busque também construílos e testá-los. É uma atividade em que o aluno, a partir de dados lingüísticos (coletados por ele ou apresentados a ele pelo professor), vai buscar criar, formular uma teoria que descreva e/ou explique os fatos sob observação, o que, no mínimo, vai ampliar sua visão dos fatos da língua, libertando-o de uma "viseira" que muitas vezes condiciona uma interpretação unívoca de uma realidade múltipla. O exemplo (13) é, na verdade, como sugerimos, um exemplo de atividade de formulação de teoria, pois, embora o professor se guie na atividade por teorias já existentes, na verdade os alunos nunca irão reconstituir exatamente a(s) teoria(s) que serviu (serviram) de base à formulação da atividade, mas criar uma outra que se aproxime de uma teoria já existente ou contenha elementos de várias delas. É diferente do que acontece no estudo dirigido. Além do mais, quantas vezes se vêem descobertas científicas muito próximas ou idênticas feitas independentemente por mais de um estudioso? Vejamos em (15) um exemplo desse tipo de atividade para que se tenha uma idéia mais concreta do que estamos falando:

(15) O professor pode desenvolver uma atividade para formulação de uma teoria sobre os determinantes de um substantivo e que pode seguir os passos de 1 a 5 especificados a seguir. ${ }^{34}$

\section{Passo 1: Proposição da atividade}

Em primeiro lugar o professor proporá aos alunos o estudo de um fato lingüístico: os determinantes do sintagma nominal (daqui em diante SN). Pode-se falar ou não teoricamente:

a) do conceito de sintagma e da constituição do mesmo em determinado + determinante. O determinante pode vir antes do determinado (este menino) ou depois (pedras 
preciosas) ou ao mesmo tempo antes e depois ( $\mathrm{um} /$ lindo gato que me faça companbia);

b) do que seja um nome que, como determinado, caracteriza um sintagma como nominal.

Caso não se queira falar teoricamente desses conceitos, pode-se buscar uma forma de mostrar a constituição de um sintagma e, passando para o SN, mostrar que o seu determinado (tradicionalmente o "núcleo") sempre é um indicador de entidades e o(s) determinante(s) sempre dizem alguma coisa dele.

O objetivo básico da atividade / pesquisa será verificar se todos os determinantes são do mesmo tipo. Evidentemente o que os une em uma única classe é o fato de, sintaticamente, acompanharem um nome ${ }^{35}$ ou, como diz Perini (1995, cap. 13), "estarem em construção" com um nome. Para isto podem ser usados critérios de três naturezas:

a) de forma (morfológico) do determinante tais como:

- ser constituído por uma ou mais palavras, podendo a palavra isolada ou grupo de palavras ser correspondente a um ou outro tipo de constituinte ou unidade da língua, como por exemplo um sintagma preposicionado ou uma oração;

- admitir ou não flexões;

b) sintáticos tais como:

- a forma de ligação ao determinado (direta ou por meio de um conectivo);

- sua colocação: só antes do determinado, só depois do determinado, antes ou depois do determinado;

- a possibilidade de concordar ou não em gênero e número com o determinado.

c) semântico que é basicamente o tipo de noção de significado que expressam, ou dito de outro modo, o tipo de instrução de sentido que contêm e o tipo de efeito de sentido que permitem. 
Passo 2: Levantamento de dados

Uma vez proposta a atividade, o primeiro passo é fazer com que os alunos levantem um corpus de dados pertinentes em textos de língua oral e/ou escrita, conforme seja desejável ou conveniente no momento. Para isto os alunos devem percorrer textos (orais e/ou escritos), recolhendo trechos em que ocorrem SNs. Ao mesmo tempo deverão marcar nos SNs encontrados os determinantes e o determinado. No final os alunos terão para observação um conjunto de dados do tipo dos exemplificados em (15.1), ${ }^{36}$ que, obviamente, é um pequeno corpus apenas para exemplificação de como realizar a atividade. $\mathrm{Na}$ atividade real convém ter um corpus maior que pode ir crescendo com o desenvolvimento da pesquisa, para incluir dados de tipos não recolhidos anteriormente.

(15.1) a - Todos / os / meus / bons / amigos vieram me ver no hospital.

b - Mande levar [à minha casa] [estes / três vestidos].

c - $A$ margarina Becel não tem colesterol.

$\mathrm{d}$ - O forte de Copacabana vai ser transformado em museu doexército.

e - Ganhei [um carro novo] [em meu aniversário] ${ }^{37}$

f - A compra da empresa / pelos japoneses surpreendeu a poucos funcionários.

g - Ele me perguntou quando começa $a$ plantação $d o$ milho.

h - A fuga dos prisioneiros teve $a$ ajuda de policiais corruptos.

i - Muitas mortes de bebês não foram explicadas.

j - Quantos alunos vieram à aula hoje?

$\mathrm{k}$ - O fim de nossa amizade surpreendeu a todos.

1 - O/ recente assassinato de Pedro / pelo pai causou grande tristeza para seusfamiliares.

m- [Aquela mulher] é [uma / grande / sábia em astronomia]. 
$\mathrm{n}$ - Várias meninas realizaram o sonho de conbecer aqueleartista.

o - Uma morte pela fome deve ser horrível.

p - Ferimentos a faca são muito perigosos, pois podem infeccionar.

q - Minha apresentação em Roma foi um sucesso.

$\mathrm{r}$ - Ele se dedica atualmente a construir casas de pedra.

s - O acompanhamento dos presos / pela escolta/para impedir fugas foi determinada pelo general.

t - Neste país não são permitidos casamentos por procuração.

$\mathrm{u}$ - Todos devem levar suprimentos para uma semana.

v - Uma nuvem de gafanhotos destruiu inúmeras lavouras.

w - A chácara de Pedro é maravilhosa.

$\mathrm{x}$ - Dizem que mulher deolbos verdesé muito ciumenta.

$y$ - $A$ aflição de ver o filho preso acabou com Maria.

z - Amigo, não posso aceitar tua oferta de empréstimo I para pagar minha cirurgia.

A - Todos se espantaram com sua chegada em janeiro.

$B$ - $A$ confecção deste violino foi trabalhosa.

$C$ - A doação de livros / à biblioteca foi uma boa opção.

D -Comprei um quilo de bombons.

E - Ele me enviou um cesto de frutas.

F - De manhã vimos um bando de patos.

$\mathrm{G}$-Coloque mais um copo de polvilho.

$H$ - $A$ menina que quebrou o braço foi atendida de imediato.

Passo 3: Classificação morfológica dos determinantes

3.1 - Os alunos poderão ser levados a observar que os determinantes nos SN podem ser constituídos: 
a) por uma única palavra. Poderemos chamá-los de "lexicais". Exemplos: Todos, os, meus, bons (15.1.a); estes, três (15.1.b); Becel (15.1.c) um, novo (15.1.e); corruptos (15.1.h); muitas (15.1.i); Quantos (15.1.j); Várias (15.1.n); verdes (15.1.x); A (15.1.H) etc.;

b) por um sintagma, geralmente preposicionado. Podemos chamá-los de "sintagmáticos". É o caso de "de Copacabana" (em 15.1.d); "da empresa" e "pelos japoneses" (em 15.1.f); "dos prisioneiros" e "de policiais corruptos" (em 15.1.h); "em astronomia" (em 15.1.m); "pela fome" (em 15.1.o); "por procuração" (em 15.1.t); etc.;

c) por uma oração. Podemos chamá-los de "oracionais". É o caso de "de conhecer aquele artista" (em 15.1.n); "para impedir fugas" (em 15.1.s); "de ver o filho preso" (em 15.1.y); "para pagar minha cirurgia" (em 15.1.z); "que quebrou o braço" (15.1.H)

A proposição de nomenclatura para designar as categorias ou classes de determinantes que forem sendo encontradas pelos diversos critérios é parte fundamental dessa atividade, pois mostra como surgem as nomenclaturas. Pode-se mostrar aos alunos que se pode dar nomes que, como os propostos acima, já dizem algo sobre a categoria, ou nomes inteiramente novos, não comprometidos com outros conceitos em outras teorias, bem como identificações absolutamente neutras como, por exemplo, determinantes do tipo 1, do tipo 2 e do tipo 3. Nos próximos passos não vamos mais comentar essa possibilidade de várias denominações.

3.2 - Quanto ao critério da possibilidade ou não de flexão do determinante, a observação do corpus (15.1) pode levar à constatação de que há determinantes do SN que se flexionam e que a flexão se dá sempre para expressão das categorias de gênero e número. A partir daí pode-se observar que é possível 
fazer a proposição de quatro classes de determinantes, conforme seu comportamento flexional:

a) os flexionáveis- $1,{ }^{38}$ que podem variar em gênero e número: como Todos, os meus, bons (em 15.1.a); estes (em 15.1.b); A (em 15.1.c, g, h); O (em 15.1.d); um, novo e meu (em 15.1.e); os (em 15.1.f); muitas (15.1.i); Aquela (15.1.m); uma (em 15.1.o); minha (15.1.q), etc.

b) os flexionáveis-2, que podem variar só em gênero: sem ocorrências no corpus de 15.1, mas parece ser possível, talvez somente no caso registrado em (15.2);

c) os flexionáveis-3, que podem variar só em número: como recente (em 15.1.1); verdes (em 15.1.x). Há outros casos, embora não muito numerosos como: cortês/corteses, feliz/ felizes, atroz/atrozes, gentil/gentis, senil/senis que todavia não aparecem no corpus de (15.1);

d) não-flexionáveis: como três (em 15.1.b); Becel (em 15.1.c); de Copacabana e do exército (em 15.1.d); da empresa e pelos japoneses (15.1.f); do milho (15.1.g); de policiais corruptos e dos prisioneiros (em 15.1.h); de conhecer aquele artista (em 15.1.n); para impedir fugas (em 15.1.s); de ver o filho preso (em 15.1.y); para pagar minha cirurgia (em 15.1.z); que quebrou o braço (15.1.H); etc.

\section{(15.2) a- Maria comprou dois cadernos.}

b- Maria comprou duas blusas.

Como já se tem dois tipos de classes de determinantes, pode-se tentar correlacionar as classes das duas classificações. Observa-se que os determinantes flexionáveis dos tipos 1, 2 e 3 são sempre "lexicais" e que todos os "sintagmáticos" e "oracionais" são não-flexionáveis. Isso é uma tendência que constitui uma regularidade que não pode ser ignorada e devese ficar atento para verificar se ela será pertinente para a descrição e/ou explicação de algum fato, permitindo fazer alguma 
generalização, o que é importante em uma teoria. Deve-se a cada passo instigar o aluno na busca e descoberta de regularidades e generalizações possíveis, para a composição da teoria.

Todavia não se pode ignorar os "lexicais não-flexionáveis" e tentar buscar uma explicação para esse fato, já que os lexicais não-flexionáveis aparentemente não são muito numerosos. A partir dos poucos exemplos encontrados no corpus de (15.1), pode-se levantar as hipóteses de que os lexicais não-flexionáveis seriam os nomes próprios e os indicadores de quantidade e buscar mais dados para verificar essas hipóteses, comprovando-as ou falsificando-as.

Um procedimento metodológico bastante frutífero nesse tipo de atividade é, sempre que possível, apresentar e encontrar dados que sejam problemáticos ou que invalidem conclusões a que já se chegou (muitas vezes pela observação de uma quantidade reduzida de dados), obrigando assim à reflexão com vistas a reestruturar a teoria até então proposta a fim de resolver os novos problemas encontrados. Assim, por exemplo, a hipótese de que um determinante lexical que indica quantidade será não-flexionável cai diante de exemplos como os de (15.2) e outras ocorrências no corpus de (15.1), tais como: Todos (a,f), Muitas (i), Quantos (j), Várias (n), Uma (v).

\section{Passo 4: Classificação sintática dos determinantes}

4.1 - Tendo verificado que muitos determinantes do SN podem se flexionar em gênero e número, pode-se observar se eles concordam e com o quê e em quê. Certamente os alunos chegarão à conclusão (já conhecida nas teorias existentes) de que o determinante do $\mathrm{SN}$ concorda em gênero e/ou número com o determinado. Obviamente, a classe dos flexionáveis é a que pode concordar e a classe dos não-flexionáveis não poderá concordar, já que a flexão é requisito básico para este processo sintático. 
4.2 - No que diz respeito ao critério da forma de ligação do determinante ao determinado no SN, o aluno poderá observar que há duas classes de determinantes:

a) Os que se ligam diretamente ao determinado. Pode-se de chamá-los de "diretos". São exemplos dessa classe todos os determinantes constituídos por uma única palavra (os lexicais);

b) Os que se ligam ao determinado com o auxílio de um tipo de palavra que se pode chamar de conectivo ou conector ou ligador. Podemos chamá-los de "indiretos". São exemplos dessa classe todos os constituídos por mais de uma palavra (os sintagmáticos e os oracionais). Evidentemente, esses são constituídos por, no mínimo, duas palavras: um ligador/ conector/conectivo + outra palavra.

O modo como apresentamos os exemplos já constitui uma porta para a generalização a que os alunos podem chegar, quando fizerem o levantamento dos exemplos dos determinantes "diretos" e "indiretos".

4.3 - Não vamos apresentar ou discutir aqui as conclusões sobre a colocação dos determinantes, mas há muitos fatos interessantes a serem observados. Muitos fatos sobre a colocação dos determinantes no SN estão disponíveis nas gramáticas e estudos lingüísticos em geral. Mas, de modo geral, pode-se perceber que entre os lexicais há grupos de determinantes que só ocorrem antes do determinado (como o, um e suas flexões), outros que só vêm depois e outros que aparecem tanto antes quanto depois. Parece que os determinantes sintagmáticos e os oracionais só podem vir depois do determinado. O professor e seus alunos podem se divertir neste campo de estudo com essas três possibilidades de colocação de determinantes. 


\section{Passo 5: Classificação semântica dos determinantes}

Observando os determinantes encontrados e analisando os tipos de instrução de sentido que contêm, o tipo de efeito de sentido que permitem, o aluno poderá constatar que os determinantes de SN podem exprimir, basicamente, as noções especificadas em (15.4). É evidente que, em um corpus mais amplo que (15.1), podem ser encontradas outras noções.

Para chegar a um elenco de noções como o proposto em (15.4), o pesquisador muitas vezes terá que tomar decisões sobre as categorias que convém incluir na teoria. Assim, por exemplo, diante de SNs como os de (15.3), é preciso decidir se os determinantes "de pedra" e "de olhos" vão ser considerados como caracterizadores dos determinados ou se é melhor ser mais específico dizendo que, em um, há indicação de matéria ou material (de pedra) e, no outro, de especialidade profissional (de olhos). Como se pode perceber, na proposta de classificação semântica dos determinantes feita acima, fez-se a opção pela primeira alternativa.

(15.3) a - No topo do morro havia uma casa de pedra.

b - Ele precisa consultar um médico de olhos.

A análise do corpus (15.1) poderia permitir chegar à classificação semântica dos determinantes especificada em (15.4).

(15.4) Nos sintagmas nominais (SNs) do Português, semanticamente, podemos ter determinantes de:

1) tempo: indicam o momento ou o período de ocorrência de um fato / situação expresso(a) pelo determinado. Exemplos: "para uma semana"(15.1.u), "em janeiro" (15.1.A);

2) lugar: indicam o lugar de ocorrência de um fato / situação expresso(a) pelo determinado. Exemplos: "em Roma" (15.1.q); 
3) finalidade: indicam a finalidade, o fim, o propósito de ocorrência / realização de um processo / fato / situação expresso(a) pelo determinado. Exemplos: "para impedir fugas" (15.1.s), "para pagar minha cirurgia" (15.1.z);

4) causa: indicam a causa, a razão, a justificativa por que ocorre um processo / um fato / uma situação expresso(a) pelo determinado. Exemplos: "pela fome" (15.1.o), "de ver o filho preso" (15.1.y);

5) instrumento: indicam o instrumento para realização de um processo / um fato / uma situação expresso(a) pelo determinado. Exemplos: "a faca" (15.1.p), "por procuração" (15.1.t),

6) agente: indicam a entidade que realiza o processo expresso pelo determinado. Exemplos: "pelos japoneses" (15.1.f), "dos prisioneiros" (15.1.h), "de policiais corruptos" (15.1.h), "pelo pai" (15.1.1), "pela escolta" (15.1.s);

7) objeto: indicam a entidade sobre a qual incide o processo expresso pelo determinado. Esta entidade pode ser o afetado ou o resultante do processo. Exemplos: "da empresa" (15.1.f), "do milho" (15.1.g), "de bebês" (15.1.i), "de nossa amizade" (15.1.k), "de Pedro" (15.1.1), "dos presos" (15.1.s), "de empréstimo" (15.1.z), "deste violino" (15.1.B), "de livros" (15.1.C);

8) destinatário: indica a entidade que é beneficiada ou prejudicada pelo (à qual se destina o) processo expresso pelo determinado. Exemplos: "à biblioteca" (15.1.C);

9) quantidade: indica quantidade da entidade expressa pelo determinado. Exemplos: "Todos"(15.1.a,u,A), "três"(15.1.b), "poucos" (15.1.f), "Muitas" (15.1.i), "Quantos" (15.1.j), "Várias" (15.1.n), "um" (15.1.D, E, F, G), "uma" (15.1.u), "inúmeras" (15.1.v); 
10) entidade conhecida: indica que a entidade expressa pelo determinado já é conhecida pelos falantes de alguma forma. Exemplos: "O(s)" e "do(s)" (15.1.a,d,g,k,l,n,s), "A" e "d $a$ " (15.1.c,f,g,h,w,y,B,C), "pelo(s)" (15.1.f,l,s), "pela" (15.1.s);

11) entidade desconhecida: indica que a entidade expressa pelo determinado ainda não é conhecida pelos falantes. Exemplos: "um" (15.1.e,), "uma" (15.1.m,o,v,C);

12) apontador: indica a presença da entidade expressa pelo determinado, na situação de comunicação, apontando para ela, como próxima ou mais afastada do falante. Exemplos: "este(s)" (15.1.b), "neste" (15.1.t), "aquele, aquela" (15.1.m,n);

13) possuidor: indica o possuidor da entidade expressa pelo determinado. Exemplos: "meu(s), minha(s)" (15.1.a,b,e,q,z), "nosso(s), nossa(s)" (15.1.k), "seu(s), sua(s)" (15.1.1,A), "tua" (15.1.z), "do exército" (15.1.d), "de Pedro" (15.1.w);

14) caracterizador: indicam uma característica da entidade expressa pelo determinado. Exemplos: "bons" (17.1.a), "novo" (15.1.e), "corruptos" (15.1.h), "recente" (15.1.1), "grande" (15.1.1,m), "em astronomia" (15.1.m), "de pedra" (15.1.r), "de olhos verdes" (15.1.x), "verdes" (15.1.x), "boa" (15.1.C);

15) especificador: especifica um elemento de alguma forma relacionado com a entidade expressa pelo determinado. Esse determinado quase sempre é um coletivo (nuvem, bando), um nome de medida ou usado como tal (quilo, cesto, copo) ou um nome que indica uma situação / processo / fala que pode ter vários conteúdos diversos e se especifica o conteúdo em pauta (sonho). Exemplos: "de conhecer aquele artista" (15.1.n), "de gafanhotos" (15.1.v), "de bombons" (15.1.D), "de frutas" (15.1.E), "de patos" (15.1.F), "de polvilho" (15.1.G); 
16) denominador: indica o nome específico e particular de uma entidade da classe expressa pelo determinado. Exemplos: "Becel" (15.1.c), "de Copacabana" (15.1.d).

O professor poderá levar os alunos a discutirem questões relativas às categorias adotadas. Assim, por exemplo, a categoria dos determinantes denominadores não poderia ser parte da categoria dos especificadores? A favor dessa opção há o argumento de que em vez de especificarem uma classe, especificam um indivíduo pela apresentação de seu nome próprio, particular: entre todas as margarinas estou falando da Becel (15.1.c). Há argumentos contra esta possibilidade?

A classificação de alguns dos determinantes apresentada acima como exemplo de cada categoria pode ser problemática, já que ele podem ser compatíveis com mais de uma categoria. Estão nesse caso, por exemplo:

a) "de Copacabana" (15.1.d), que colocamos como denominador, mas pode ser visto por alguns como determinante de possuidor;

b) "do exército" (15.1.d), que classificamos como determinante de possuidor, entendendo o exército como o "dono" e "administrador" do museu. Todavia pode-se entender "exército" como o tema, o assunto do museu. Nesse caso "do exército" será uma caracterização do museu e esse determinante seria um caracterizador;

c) "um" (15.1.e), "uma" (15.1.v) foram colocados como determinantes de "entidade desconhecida", mas também são ambíguos, porque há a possibilidade de se interpretar que eles indicam quantidade.

A ambigüidade observada na classificação dos determinantes é um fato real com o qual uma teoria sobre os mesmos terá que tratar e do qual deve dar conta. Os alunos podem buscar uma forma de explicar teoricamente tal ambigüidade, para resolver casos como o do sintagma "foto de João", presente no trecho de (15.5). É fácil perceber que "de João" pode ter três interpretações: 
a) como agente (foto que João tirou, fez. Ele foi o fotógrafo);

b) como objeto (João foi fotografado. É ele que aparece estampado na foto);

c) como possuidor (João é o dono da foto, ela lhe pertence, mas ele pode nem aparecer nela).

Os alunos podem propor que ter-se-ia três determinantes homônimos e que a determinação de qual estaria presente em um dado texto dependeria de um co-texto maior ou de um conhecimento de mundo ampliado e/ou do contexto de situação imediata que permitisse decidir qual efeito de sentido é o que está em jogo. Ou seja, precisar-se-ia ter algo como o especificado em (15.6). Essa é uma possibilidade de tratamento da questão, talvez a mais fácil de se propor e aceitar. Há outra(s)? Qual (Quais)?

(15.5) Gostei muito d[ $a$ foto de João].

(15.6) a - Meus amigos ganharam fotos de pássaros, quando visitaram o zoológico. Eu as vi ontem. Gostei muito da foto de João. (O co-texto maior, permite ampliar um conhecimento de mundo - o que está na foto e um conhecimento da situação imediata de comunicação que favorecem a interpretação de "de João" como possuidor).

b - Num concurso de fotografias, um dos juízes, após examinar as fotos feitas por várias pessoas diz o texto de (15.5). Nesse contexto de situação imediata de comunicação tende-se a interpretar "de João" como agente: aquele que tirou a foto.

c - Uma mãe examina várias fotos de seus filhos (João, Raul, Luísa), que lhe foram apresentadas por um parente que as fez. Após olhar as fotos, ela diz o texto de (15.5). Novamente a situação imediata de comuni-cação torna uma interpretação preferencial, 
eliminando a ambigüidade: "de João" será interpretado como objeto: João é a pessoa fotografada.

Como se pode ver na atividade de (15), os procedimentos básicos para formular uma teoria estão presentes. Colocamos em cada passo um possível resultado, para que o leitor perceba mais claramente os caminhos que devem ser percorridos, mas isso não deve ser tomado, em nenhuma hipótese, como a única formulação teórica possível para o tema da atividade. Além disso, como preconizamos, muitas possibilidades de estudo se abriram e permaneceram inexploradas, mas cremos que isso serviu para mostrar que qualquer tópico que tomarmos poderá motivar e fornecer material para uma atividade por meio da qual se ensina a pensar, a raciocinar, a fazer ciência e a aprender que o conhecimento pode ser construído por todos nós.

Além dos exemplos de (13) e (15), sugerimos a leitura do exemplo apresentado por TRAVAGLIA (1996, cap. 12). Ali se apresenta uma atividade de formulação de teoria em que o aluno é levado:

a) a propor uma classe de recursos da língua que podem ser denominados de caracterizadores de entidades (essa classe dos caracterizadores incluiria: a classe de palavras tradicionalmente classificada como adjetivos, a locução adjetiva ou sintagma adjetivo, a oração subordinada adjetiva e o particípio que é uma forma verbal que a tradição diz ser uma forma nominal de valor adjetivo);

b) a propor classificações desses recursos em subclasses, usando critérios diversos:

- ser formado por uma única palavra ou por mais de uma palavra (um critério formal ou morfológico);

- a possibilidade de ser usado tanto anteposto quanto posposto ao termo que indica a entidade caracterizada ou poder ser usado só posposto ou só anteposto (um critério sintático); 
c) a tentar correlacionar as subclasses obtidas pelos critérios de $b$;

d) a tentar encontrar explicações ou regularidades que expliquem casos que aparentemente fogem de comportamentos padrões de colocação propostos, ao se correlacionar as classes obtidas com o segundo critério (colocação) com as obtidas pelo critério formal.

E a formulação da teoria poderia continuar por todo o tempo disponível, em novos passos que se pode facilmente conceber.

É preciso deixar claro que, no tipo de atividade que concretiza essa estratégia de criação / formulação de teorias, não interessa propriamente o resultado final, ou seja, a teoria que se formula, embora seja conveniente para a própria formação adequada dos alunos, que a teoria formulada por eles seja o mais coerente possível, atendendo o máximo possível aos princípios científicos. Todavia o fundamental é que os alunos percebam que eles, como diz PERINI (1978), "não apenas podem 'aprender' gramática, mas também 'fazer' gramática."

Outro aspecto no desenvolvimento desse tipo de atividade é que não é necessário ter pressa. Os passos para a formulação da teoria devem ser feitos um a um com o maior cuidado possível. Os alunos devem ser incentivados: a) na coleta dos dados; b) na observação dos mesmos; c) no levantamento de hipóteses; d) na testagem das mesmas, falsificando-as ou comprovando-as frente aos dados; e) na busca de contra-exemplos; f) na busca de explicacões para determinados fatos lingüísticos; g) na proposição de terminologia ou nomenclatura para designar elementos lingüísticos de diferentes naturezas identificados (unidades, construções, funções, classes e/ ou subclasses de elementos lingüísticos, etc.); h) na busca de argumentos de diferentes naturezas a favor ou contra determinadas idéias, hipóteses, explicações; i) na percepção e explicitação de regularidades e generalizações da língua. Nesses passos o professor e os alunos podem gastar todo um período letivo (semestre, ano) 
na formulação e aperfeiçoamento de uma teoria, pois o que importa é a aquisição da habilidade de produzir conhecimento, o mais possível utilizando critérios e parâmetros de qualidade, buscando escapar a distorções que ideologias, preconceitos e interesses diversos, a que já nos referimos, podem impor ao conhecimento que se produz. Importa menos ou nada a quantidade de teorias que se formula.

Um aluno que desenvolvesse tais habilidades, por exemplo, no estudo do "verbo", estaria apto a estudar, a aprender e apreender qualquer item de teoria gramatical, sem a falta de resultados que tem caracterizado como infrutíferos os estudos teóricos da língua materna no Ensino Fundamental e Médio, tal como ele tem, normalmente, sido desenvolvido: por meio de atividades de memorização sem compreensão, por meio da formulação e apresentação de macetes e dicas sem pertinência e sem base científica, por meio da apresentação e imposição de uma visão única dos fatos da língua, freqüentemente com distorções inaceitáveis.

\section{3 - CONSIDERAÇÕES FINAIS}

Como se pode ver, é possível e, em certas circunstâncias, mesmo desejável / aconselhável, trabalhar com teoria gramatical ou lingüística na escola. Todavia, ao fazê-lo, o professor precisa estar atento a problemas envolvidos no ensino de teoria gramatical que vêm sendo apontados por diversos estudiosos da questão (BECHARA, 1985, LUFT, 1985, PERINI, 1978, 1986 e 1995, POSSENTI, 1996, SUASSUNA, 1995, TRAVAGLIA, 1996, entre outros). A seguir resumimos os principais problemas registrados por esses estudiosos:

1) O professor cometer o equívoco de pensar que o ensino de teoria gramatical levará o aluno a ter as habilidades desejáveis de leitura (compreensão de textos orais e escritos) e escrita (produção de textos orais e escritos), que façam dele um usuário competente da língua, no sentido de alguém que tem competência comunicativa. 
2) O professor não considerar que o ensino teórico de gramática pode ser feito para atender objetivos educacionais mais gerais como ensinar a pensar, ensinar o raciocínio científico, para observação, descrição e explicação de fatos ou fenômenos do mundo natural e/ou social, desenvolvendo a habilidade intelectual de produzir conhecimento. Esses objetivos não estão ligados diretamente à educação lingüística, ${ }^{39}$ mas são altamente desejáveis, inclusive no ensino de língua materna.

3) O professor apresentar uma teoria ou hipótese de descrição e explicação da língua e seu funcionamento como uma verdade irrefutável e não como uma tentativa de descrição / explicação, que pode ter e geralmente tem problemas. Esses problemas geralmente têm a ver com os fatos: a) de a teoria ou hipótese não serem capazes de dar conta de todos os fenômenos da língua ligados ao ponto em foco; b) de a teoria ou hipótese gerarem equívocos na visão que se tem sobre a constituição e funcionamento da língua. Portanto isso põe a possibilidade de se mostrar os problemas da teoria e não de tentar com "macetes" ou com escolha tendenciosa de dados (exemplos) fazer pensar (pelas mais diversas razões, incluindo nosso desconhecimento mais amplo dos estudos lingüísticos) que a teoria dada é algo sem problemas e que os problemas porventura encontrados se devem apenas à incapacidade intelectual dos alunos.

4) O professor trabalhar apenas com determinada visão da língua, dada por uma única teoria ou corrente lingüística, sem lembrar, ou pior, sem admitir que diferentes abordagens podem nos mostrar diversas facetas, igualmente válidas ou reais, sobre dado fato ou fenômeno da língua.

5) O professor não ter consciência de como e porque dada teoria foi formulada. Não conhecer seus propósitos, pressupostos, sua origem e, sobretudo, não ter consciência de problemas e falhas que ela apresenta, mesmo que tenha muitas qualidades e sirva muito bem para trabalhar com determinados fatos da língua, seja 
do ponto de vista da descrição / explicação da língua e seu funcionamento, seja do ponto de vista de controle de atividades no que respeita ao uso, para diferentes finalidades, dos conhecimentos e análises lingüísticos (por exemplo, nos diversos campos da Lingüística Aplicada). Pior ainda é ter consciência de problemas e falhas e buscar ocultá-los dos alunos, tirando-lhes a oportunidade de entender melhor como se faz ciência e a que serve ela serve.

A desatenção a tudo o que foi dito aqui é que leva o ensino de teoria sobre a língua materna a ser visto e classificado como maléfico (BECHARA, 1985, LUFT, 1985), uma tortura (LEMINSKI, 199?), equivocado, distorcido e mal estruturado (PERINI, 1995, POSSENTI, 1996 e TRAVAGLIA, 1996).

Muitos poderão se perguntar se um ensino de teoria gramatical nos moldes aqui propostos não confundiria o aluno, levando-o a falhar, numa prova de seleção ou avaliação em circunstâncias escolares ou não-escolares (como concursos, por exemplo), na qual lhe pedissem para fazer coisas como: a) encontrar e indicar (sublinhando, marcando, destacando, etc.) tipos ou classes de elementos lingüísticos (como advérbios, substantivos, gramemas, por exemplo); b) classificar elementos da língua indicados, usando nomenclatura própria de uma dada teoria $;{ }^{40}$ c) realizar análises de elementos da língua; d) etc. Pode-se responder a essa preocupação, lembrando que um ensino com uma tal visão crítica abriria tanto os horizontes dos alunos que, certamente, a falha (ou, se se preferir, o erro e a dúvida) em tal tipo de atividade seria largamente compensado pelo "acerto" em questões, sem dúvida mais pertinentes à avaliação de conhecimentos e habilidades de pessoas. É preciso lembrar ainda que a força dos alertas da Lingüística Aplicada tem feito, felizmente, que, cada vez mais, os professores e mesmo outros profissionais, que elaboram provas de seleção e avaliação, evitem formular questões que cobram um conhecimento lingüístico engessado por uma visão reducionista e distorcida da ciência lingüística e sem qualquer relação com o uso e funcionamento da língua. 
Nossa intenção, nesta exposição, não foi defender que o professor deve ensinar teoria gramatical no Ensino Fundamental e Médio, mas mostrar que o professor pode, por razões diversas, optar por ensinar teoria gramatical ou lingüística a seus alunos. Todavia, se o fizer, deve fazê-lo consciente de vários fatos e fatores que não podem ser esquecidos para não incorrer numa atitude inconseqüente caracterizada por:

a) fazer algo sem saber por que, como, com que finalidade, achando que o ensino de teoria pode, por exemplo, formar um usuário da língua competente comunicativamente;

b) ensinar teoria por desconhecer outras possibilidades para o ensino de língua materna;

c) ou, pior de tudo (por ter um componente de má fé e/ou de irresponsabilidade profissional), ensinar teoria gramatical porque é mais cômodo e fácil, inclusive porque é o que mais se tem feito, é o que está estabelecido como imagem do que seja o ensino de língua materna e, por isso mesmo, dificilmente será questionado por alguém e exigirá de nós posturas profissionais claras e competentes.

\section{NOTAS}

1 Agradeço aos professores Maria Luiza Braga (UFRJ), Sebastião Carlos Leite Gonçalves (UNESP - São José do Rio Preto), Andréia Mendes (UFRJ) e Neuza Gonçalves Travaglia (UFU) a leitura da primeira versão deste artigo e suas sugestões pertinentes. As falhas que o artigo apresente continuam sendo de minha responsabilidade.

${ }^{2}$ Embora muitos distingam a gramática da descrição feita pela lingüística, reservando para a gramática apenas a descrição que se faz da língua culta escrita e as recomendações de caráter normativo daí derivadas, para nós, teoria gramatical ou lingüística se entende como toda e qualquer descrição da língua em qualquer nível (fonológico, morfológico, sintático, semântico) e plano (lexical, frasal, textual), resultante dos estudos lingüísticos, realizados em qualquer época, feitos de acordo com qualquer corrente ou vertente (lingüística formal ou da enunciação) ou modelo analítico (estudos tradicionais, estruturalismo, 
transformacionalismo, funcionalismo, lingüística textual, análise do discurso, análise da conversação, semântica argumentativa, pragmática, etc.)

${ }^{3}$ Estamos neste caso do quadro mais geral, acatando sugestão de PERINI (1988) (TRAVAGLIA, 1996, cap. 12).

${ }^{4}$ Sobre a construção e utilização de exercícios estruturais ver TRAVAGLIA, ARAÚJO \& PINTO (1984).

${ }^{5}$ Esta atividade pressupõe o conhecimento teórico sobre o que é o sujeito de uma frase e o que é seu núcleo e a habilidade analítica de identificar o sujeito. A mesma observação vale para as demais atividades em que o professor usar esta terminologia: sujeito e núcleo do sujeito.

${ }^{6}$ Quando o verbo fica no singular a leitura do constituinte introduzido por "com" pode ser ambígua, sendo ele interpretado mais como um "adjunto adverbial de companhia" do que como um núcleo do sujeito. Isso pode ser visto nos exemplos dados onde se pode ter, por exemplo, leituras como: "Meu filho estudava todos os dias com seus colegas", "O noivo entrou no salão de festas com sua noiva, sorrindo alegremente" (exercício 2) e "João quando está com seus irmãos é muito alegre" (exercício 6)

${ }^{7}$ Obviamente este estudo dirigido faz com que o aluno chegue apenas à conclusão de que neste caso o verbo pode ser usado tanto no singular quanto no plural. A questão da diferença entre o singular e o plural: os sentidos possíveis para o texto com o verbo no plural ou no singular, os efeitos de sentido que podem advir dessa diferença e a adequação de usar uma ou outra forma de acordo com o que se pretende na situação, bem como considerações estilísticas e de relação com a realidade exigiriam um estudo dirigido que fosse adiante, embora acreditemos que para discussão destes aspectos seriam mais adequadas atividades de gramática reflexiva tal como proposto em TRAVAGLIA (1996).

${ }^{8}$ Para os que sentirem dificuldade devido ao fato de se usar o termo texto em relação a seqüências curtas, lembramos que estamos entendendo texto como qualquer seqüência lingüística que, independentemente de sua extensão, é tomada pelos usuários (falante, escritor / ouvinte, leitor) da língua, em uma situação específica de interação comunicativa, como uma unidade de sentido e exercendo uma função comunicativa reconhecida ou reconhecível, para a consecução de uma finalidade comunicativa (KOCH \& TRAVAGLIA, 1989, p. 8 e 9). Ou seja, não estamos tratando as seqüências desse e outros exercícios como frases, mas como textos.

9 A classificação de uma unidade da língua como uma "palavra" já é um conhecimento teórico que permite distinguir este tipo de unidade de outras tais como: fonemas, morfemas, oração, período, frase, texto, etc. 
${ }^{10}$ Não vamos expor aqui em detalhes as proposições de PERINI (1995, caps. 12 e 13), que é mais programática do que de respostas definitivas, segundo o próprio autor. Sugerimos a leitura do texto de Perini que é bastante motivador e orientador em nosso trabalho como professores e pesquisadores da língua, sobretudo no que diz respeito a deixar de lado certos "preconceitos" que têm prejudicado muito tal trabalho.

11 PERINI (1995, segunda parte: Sintaxe) define as funções sintáticas de modo diverso da teoria tradicional. Não vamos reproduzir aqui a proposta do autor.

${ }^{12}$ Preferimos dizer adequado, mas mantivemos o texto usado pelo autor já que se trata de exposição de suas idéias.

13 (9 a) é exemplo dado por PERINI (1995, p. 30).

${ }^{14} \mathrm{O}$ conhecimento de como um dicionário é organizado também ajuda na busca de informações e deve ser dado pelo professor de língua materna, mas não é um conhecimento teórico sobre a língua.

${ }^{15}$ Sobre as variedades lingüísticas e o ensino de língua materna ver TRAVAGLIA (1996, cap. 5).

${ }^{16}$ A Nomenclatura Gramatical Brasileira (NGB), proposta com fins didáticos de uniformização, para facilitar aspectos diversos no ensino de teoria gramatical, acabou tornando-se uma teoria oficial nas escolas, inclusive apagando a diversidade das teorias lingüísticas tradicionais, que ela buscou uniformizar .

${ }^{17}$ Os chamados artigos e pronomes da teoria tradicional na verdade referem ou apontam para algo do mundo biopsicofisicossocial, mas diferem de outras palavras no sentido de que podem ser usados em relação a qualquer ser, coisa, objeto, sentimento, processo, etc., porque não trazem em seu significado nenhuma referência a propriedades ou características que se veja como intrínsecas e identificadoras de cada elemento referido pela palavra, como acontece, por exemplo, com os substantivos, verbos, adjetivos e numerais da teoria tradicional. Talvez houvesse uma terceira classe de palavras por esse critério: a das "semilexicais" ou "semi-gramaticais" ou das "lexigram"?

Pode-se discutir também que alguns dos chamados advérbios referem-se a coisas do mundo biopsicofisicossocial (hoje, ontem) e então deveriam ir para a classe das palavras lexicais, o que mudaria em parte o quadro que configuraremos no passo 4. Foi esse fato que levou alguns estudiosos a falar em advérbios nominais e advérbios pronominais (Cf. MACAMBIRA, 1974 e 1976) ou em nomes e pronomes com função sintática de advérbio (CÂMARA ÚNIOR, 1970)

${ }^{18}$ A classe de palavras chamadas de interjeições pela teoria tradicional constitui um problema no estabelecimento de classes de palavras que a maioria dos 
estudiosos deixou meio de lado ao formular suas teorias. Veja-se aqui mesmo as propostas de CÂMARA JÚNIOR (1970), SCHNEIDER (1977) e PERINI (1995). Colocamo-las entre as palavras que não indicam nada do mundo biopsicofísicossocial, mas achamos esta posição discutível. No passo 4 ver-se-á que também sintaticamente elas constituem um problema.

${ }^{19}$ Um fato que, sem dúvida, pode provocar discussão é o fato de que nem todos os numerais são flexionados, mas apenas um pequeno número deles: um/uns/ uma/umas, dois/duas e todos os que a teoria tradicional chama de ordinais.

${ }^{20}$ Comportamento semelhante parecem ter os chamados marcadores conversacionais, que também não têm flexão, embora alguns tenham a forma gramatical da palavra lexical de que se formaram. Interjeições (palavras que exprimem reações emocionais) têm papel semântico / pragmático diferente dos marcadores que, na interação, têm funções tais como as de manifestar concordância, discordância, atenção ao outro, etc.

21 "Artigo é a palavra que acompanha o substantivo, determinando-o" ou "Artigo é a palavra que acompanha o substantivo indicando-lhe o gênero e o número".

${ }^{22}$ Entende-se por marca lingüística qualquer elemento da língua (morfema, palavra, etc.) que explicita uma instrução de sentido. Assim, por exemplo, em Maria não veio à aula. Ela estava doente, os recebedores do texto tenderão a estabelecer entre a idéia de Maria não vir à aula e a idéia de Maria estar doente uma relação de causa e conseqüência. Mas não há nada que instrua o recebedor do texto a fazer esta relação. Ao contrário, em Maria não veio à aula porque estava doente, o produtor do texto colocou uma marca que é a palavra (conjunção) porque, que instrui o recebedor do texto a fazer tal relação de causa e conseqüência entre as duas idéias. Portanto há uma marca para tal.

${ }^{23}$ Evidentemente a marcação se fará sempre no primeiro elemento que pode receber a marca, pois, dependendo da língua, o primeiro elemento da cadeia é de uma classe não-flexionável. Em línguas como o inglês, em que o único elemento flexionável no sintagma nominal é o nome e em que o verbo não se flexiona para marcar número, a indicação de quantidade terá que ser feita no único elemento flexionável em número, daí termos: The smart boy broke the window/ The smart boys broke the window". Não é a necessidade ou não de indicar a quantidade apenas uma ou mais de uma vez que regula, nas línguas, a quantidade de marcações e o lugar delas de forma redundante ou não. No Português a tendência para indicar o número logo no início é tão forte que se encontram usos em que o falante flexiona elementos que, em princípio, não seriam flexionáveis em número. Um exemplo disso é a flexão de que em textos como quis livros você leu?, não sei quis meninos quebraram a janela. 
${ }^{24}$ As idéias sobre advérbio aqui expostas foram colhidas em BECHARA (1973), BUENO (1968), CUNHA (1970), LIMA (1994), MACAMBIRA (1974), SAID ALI (1964) e (1965), VILELA \& KOCH (2001). Sugerimos ainda a leitura de BONFIM (1998), CASTILHO \& CASTILHO (1992) e ILARI (1990 e 1992).

${ }^{25}$ Sobre a ausência de exemplos de advérbios ou locuções adverbiais para várias circunstâncias veja-se a crítica feita nos passos 3.1 e 4.2.

${ }^{26}$ VILELA \& KOCH (2001, p. 247-248) incluem as partículas de inclusão, exclusão e designação na lista dos advérbios. BUENO (1968, p.147-148) inclui as de designação entre os advérbios. Pelos exemplos dados e pelos critérios apresentados, nota-se que MACAMBIRA (1974) inclui muitas delas na lista dos advérbios.

${ }^{27}$ Exemplos de BECHARA (1973, p.153).

${ }^{28}$ Para MACAMBIRA (1974, p. 43-44) a modificação do pronome e numeral teriam que ser incluídos na definição de advérbio, porque, antes da NGB, eles pertenciam à classe dos adjetivos.

${ }^{29}$ Estudos da gramática gerativo-tranformacional demonstraram que só o advérbio de modo refere-se especificamente ao verbo. Os demais advérbios e adjuntos adverbiais referem-se sempre ao predicado como um todo (advérbios de grau 2) e à sentença (advérbios de grau 3) (NARO \& AVERBURG, 1977)

${ }^{30}$ Quase sempre expressando um parecer subjetivo do falante, uma atitude do falante, o que colocaria os "advérbios" que assim se comportam na classe dos modalizadores, que inclui não só "advérbios", mas palavras de outras classes, construções, categorias gramaticais, etc.

31 Não estamos dizendo que uma palavra composta seja uma locução, mas sim que, para efeito de raciocínio sobre classe de palavras, as locuções podem ser equiparadas a uma palavra composta. Caso contrário seremos obrigados a incluir na classe de palavras todos os constituintes sintaticamente construídos e que possam desempenhar na seqüência lingüística a(s) mesma(s) função(ões) que as palavras de determinada classe de palavras.

${ }^{32}$ Sobre a expressão da quantidade, ver o que dissemos em TRAVAGLIA (2000). 33 Veja-se o que é comentado em 5.4 sobre advérbios interrogativos e relativos.

${ }^{34}$ Por uma questão de espaço, não vamos especificar todos os detalhes possíveis em um estudo como este para construção de uma teoria, mas o leitor poderá cooperar conosco pensando no(s) desdobramento(s) de várias possibilidades que serão indicadas, mas deixadas em aberto ou que nem mesmo referiremos. Até onde ir, já dissemos, depende do(s) objetivo(s) que se quer alcançar, das condições de tempo e do estágio de desenvolvimento dos alunos. Da mesma 
forma, não vamos apresentar todo o montante de corpus passível de ser levantado, mas daremos apenas exemplos para deixar claro o tipo de material lingüístico envolvido.

35 Pode-se trabalhar com os determinantes do que tradicionalmente se tem chamado de substantivos, adjetivos e advérbios nominais. Aqui vamos limitar os exemplos apenas a determinantes de substantivos. Começam aqui as possibilidades não desenvolvidas no exemplo a que nos referimos na nota 34 .

${ }^{36}$ Nos exemplos em (15), adotou-se a seguinte convenção: itálico: determinante; negrito: determinado; itálico e negrito: o elemento assim marcado é ao mesmo tempo uma parte de um determinante que funciona como determinado em relação a algum outro elemento da seqüência lingüística; barra (/): separação de diferentes determinantes em seqüência; colchetes [ ]: isola um sintagma nominal de outro, quando eles aparecem em seqüência.

$37 \mathrm{Na}$ verdade, quando o sintagma começa por uma preposição é um SPrep (sintagma preposicionado). Para o nível dos alunos essa distinção não precisa ser feita, porque pode-se considerar que é um sintagma nominal acompanhado de um conector/conectivo/ligador. Foi o que fizemos nesse exemplo de proposição de uma teoria.

${ }^{38}$ Evidentemente, em uma pesquisa, só se pode dizer que algo é flexionável se se observar as diversas formas gramaticais da palavra. Aqui pelas limitações do corpus colocado em (15.1), pode-se constatar apenas a flexão de alguns elementos. Todavia pode-se contar com a intuição de falante nativo da língua, que pode conhecer formas que não estão disponíveis no corpus.

39 Sobre o conceito de "educação lingüística" ver TRAVAGLIA, 1998a.

${ }^{40}$ Nem mesmo com relação à nomenclatura técnica existe consenso.

\section{REFERÊNCIAS BIBLIOGRÁFICAS}

BASTOS, Lúcia Kopschitz; MATTOS, Maria Augusta. A produção escrita e a gramática. São Paulo: Martins Fontes, 1986.

BECHARA, Evanildo. Moderna gramática portuguesa (Cursos de $1^{\underline{0}}$ e $2^{\underline{o}}$ graus). São Paulo: Nacional, 1973.

. Ensino de gramática. Opressão? Liberdade? São Paulo: Ática, 1985.

BONFIM, Eneida do Rego Monteiro. Advérbios. São Paulo: Ática, 1998.

BUENO, Francisco da Silveira. Gramática normativa da Língua Portuguesa (Curso Superior). São Paulo: Saraiva, 1968. 
CÂMARA JÚNIOR, Joaquim Mattoso. Estrutura da Lingua Portuguesa. Petrópolis: Vozes, 1970.

. Dicionário de filologia e gramática. Rio de Janeiro: J. Ozon, 1974.

CASTILHO, Ataliba Teixeira de; CASTILHO, Célia M. de. Advérbios focalizadores. In: ILARI, Rodolfo (Org.). Gramática do Português falado. Vol. II: Níveis de análise lingüística. Campinas, SP: Editora da UNICAMP, 1992.

CEGALLA, Domingos Paschoal. Novíssima gramática da Lingua Portuguesa. São Paulo: Nacional, 1976.

CUNHA, Celso. Gramática do Português contemporâneo. Belo Horizonte: Bernardo Alvares, 1970.

FERREIRA, Maria Cristina L. Leitura crítica da gramática escolar sob a ótica lingüístico-ideológica. Letras \& Letras, Uberlândia, Universidade Federal de Uberlândia, v. 2, n. 1, p. 47-62, mar. 1986.

HAUY, Amini Boainain. Da necessidade de uma gramática-padrão da Língua Portuguesa. São Paulo: Ática, 1983.

HOUAISS, Antônio; VILlAR, Mauro de Salles. Dicionário Houaiss da Língua Portuguesa. Rio de Janeiro: Objetiva, 2001.

IGNÁCIO, Sebastião Expedito. Por exemplo, o ensino de análise sintática. Alfa, São Paulo, UNESP, n. 37, p. 33-41, 1993.

ILARI, Rodolfo et al. Considerações sobre a posição dos advérbios. In: CASTILHO, Ataliba Teixeira de (Org.). Gramática do Português falado. Vol. I: A ordem. Campinas: Editora da UNICAMP/FAPESP, 1990. p. 63-141.

ILARI, Rodolfo. Sobre os advérbios aspectuais. In: ILARI, Rodolfo (Org.). Gramática do Português falado. Vol. II: Níveis de análise lingüística. Campinas: Editora da UNICAMP, 1992. p. 152-192.

KATO, Mary Aizawa. A conceitualização gramatical na história, na aquisição e na escola. Trabalhos em lingüística aplicada, Campinas: IEL/UNICAMP, n. 12, p. 13-22, jul.-dez. de 1988.

KOCH, Ingedore Villaça. A coesão textual. São Paulo: Contexto, 1989. . A inter-ação pela linguagem. São Paulo: Contexto, 1992.

KOCH, Ingedore Grunfeld Villaça; TRAVAGLIA, Luiz Carlos. Texto e coerência. São Paulo: Cortez, 1989.

LEMINSKI, Paulo. Por falar em tortura. Folha de S. Paulo, São Paulo, [dados desconhecidos], 199?

LIMA, Rocha. Gramática normativa da Lingua Portuguesa. Rio de Janeiro: José Olympio, 1994. (1 $1^{\mathrm{a}}$ ed.: 1972). 
LOPES, Oscar. Necessidade de um mínimo de consciência formal da língua na prática escolar. In: Actas do $1^{\circ}$ encontro nacional para a investigação e ensino do Português. Lisboa: Centro de Lingüística das Universidades de Lisboa, Porto, Coimbra, Aveiro e Braga, 1976. p. 377-390.

LUFT, Celso Pedro. Língua e liberdade: por uma nova concepção da língua materna e seu ensino. Porto Alegre: L \& PM, 1985.

MACAMBIRA, José Rebouças. A estrutura morfo-sintática do Português. São Paulo: Pioneira, 1974. . Português estrutural. São Paulo: Pioneira, 1976.

MARQUARDT, Lia Lourdes; GRAEFF, Telisa Furlanetto. Ensino de gramática e desenvolvimento de raciocínio. Letras de Hoje, Porto Alegre, PUC-RS, v. 21, n. 3, p. 7-35, dez. 1986. (Ou In: TASCA, Maria (Org.). Desenvolvendo a lingua falada e escrita. Porto Alegre: Sagra, 1990. p.119-145).

NARO, Anthony Julius; AVERBURG, Marilda Winkler. Introdução aos estudos da gramática gerativa-transformacional. Rio de Janeiro: PUC-RJ, 1977. Cópia de inédito.

PERINI, Mário A. Sobre a classificação de palavras do ponto de vista da Sintaxe. In: Subsidios à proposta curricular de Lingua Portuguesa para $2^{\circ}$ grau - V. IV: Variação lingüística e ensino de lingua materna. São Paulo: CENP / SEE, 1978.

. Para uma nova gramática do Português. São Paulo: Ática, 1985.

. Ensinar gramática: sim ou não?. In: Anais do II Seminário Integrado de Ensino de Língua e Literatura. Porto Alegre: PUC-RS/Yázigi. 1986. p. 3-15.

. Níveis de detalhamento na descrição gramatical: uma perspectiva pedagógica. In: Trabalbos em lingüística aplicada, Campinas: IEL/UNICAMP, n. 12, p. 23-32, jul.-dez. de 1988.

. Sintaxe portuguesa-metodologia e funções. São Paulo: Ática, 1989.

. Gramática descritiva do Português. São Paulo: Ática, 1995.

POSSENTI, Sírio. Por que (não) ensinar gramática na escola. Campinas, SP: ALB/ Mercado de Letras, 1996.

ROCHA LIMA, Carlos Henrique da. Gramática normativa da Língua Portuguesa. Rio de Janeiro: José Olympio, 1973.

SAID ALI, Manuel. Gramática histórica da Língua Portuguesa. São Paulo: Melhoramentos, 1964.

1965.

. Gramática secundária da Língua Portuguesa. São Paulo: Melhoramentos, 
SCHNEIDER, Cristina. Tentativa de classificação dos vocábulos segundo um critério morfológico. Rio de Janeiro: PUC-RJ, 1977. Cópia de inédito. 6p.

SUASSUNA, Lívia. Ensino de Lingua Portuguesa: Uma abordagem pragmática. Campinas, SP: Papirus, 1995.

TRAVAGLIA, Luiz Carlos. Integração entre ensino de gramática e ensino de produção/compreensão de textos e de léxico. In: HEYE, Jurgen (Org.). Flores verbais - Uma miscelânea em homenagem à Eneida do Rego Monteiro Bomfim no seu 70a aniversário. Rio de Janeiro: PUC-RJ, 1995. p. 103- 119.

. Gramática e interação: uma proposta para o ensino de gramática no $1^{\circ}$ e 2o graus. São Paulo: Cortez, 1996.

Ensino de gramática numa perspectiva textual-interativa. In: AZAMBUJA, Jorcelina Queiroz (Org.). O ensino de lingua portuguesa no $2^{\circ}$ grau. Uberlândia: EDUFU, 1996a: 107-156.

. (1997). Ensino de gramática em uma perspectiva textual-interativa e qualidade de vida. In: HILGERT, José Gaston et alii (Org.). Formando uma sociedade leitora. Passo Fundo, RS: EDIUPF (Editora da Universidade de Passo Fundo), 1999. p. 237-242.

. Ensino de língua materna - Gramática e texto: alguma diferença? Letras ELetras, Uberlândia: Editora da Universidade Federal de Uberlândia, v.14, n. 1, p. 171-179, jan.-jul. 1998.

. Universidade e educação lingüística. Revista da UNICSUL - A Universidade no século XXI - Desafios e perspectivas. São Paulo: Universidade Cruzeiro do Sul, ano 3, n. 4, p. 85-98, ago. 1998a.

A sistematização do ensino de gramática em atividades de gramática reflexiva e outras. In: BASTOS, Neusa Barbosa (Org.). Discutindo a prática docente em Lingua Portuguesa. São Paulo: IP - PUC/SP, 2000. p. 59-70.

TRAVAGLIA, Luiz Carlos; ARAÚJO, Maria Helena Santos; PINTO, Maria Teonila de Faria Alvim (1984). Metodologia e prática de ensino da Língua Portuguesa. Uberlândia: EDUFU, 1995 ( $\left.3^{\mathrm{a}} \mathrm{ed}\right)$.

VILELA, Mário; KOCH, Ingedore Villaça. Gramática da Língua Portuguesa (Gramática da palavra. Gramática da frase. Gramática do texto/discurso). Coimbra: Almedina, 2001. 